Defraeye T., Aregawi W., Saneinejad S., Vontobel P., Lehmann E., Carmeliet J., Verboven P., Derome D., Nicolai B. (2013), Novel application of neutron radiography to forced convective drying of fruit tissue, Food and Bioprocess Technology, (DOI:10.1007/s11947-012-0999-y)

Publisher version can be found at: http://link.springer.com/article/10.1007\%2Fs11947-012-0999-y

\title{
Novel application of neutron radiography to forced convective drying of fruit
}

\section{tissue}

Thijs Defraeye ${ }^{\mathrm{a},{ }^{*}}$, Wondwosen Aregawi ${ }^{\mathrm{a}}$, Saba Saneinejad ${ }^{\mathrm{c}, \mathrm{d}}$, Peter Vontobel ${ }^{\mathrm{e}}$, Eberhard Lehmann ${ }^{\mathrm{e}}$, Jan Carmeliet $^{\mathrm{c}, \mathrm{d}}$, Pieter Verboven ${ }^{\mathrm{a}}$, Dominique Derome ${ }^{\mathrm{d}}$, Bart Nicolai ${ }^{\mathrm{a}, \mathrm{b}}$

${ }^{a}$ MeBioS, Department of Biosystems, University of Leuven, Willem de Croylaan 42, 3001 Heverlee, Belgium

${ }^{b}$ VCBT, Flanders Centre of Postharvest Technology, Willem de Croylaan 42, 3001 Heverlee, Belgium

${ }^{c}$ Chair of Building Physics, Swiss Federal Institute of Technology Zurich (ETHZ), Wolfgang-Pauli-Strasse 15, 8093 Zürich, Switzerland

${ }^{d}$ Laboratory for Building Science and Technology, Swiss Federal Laboratories for Materials Testing and Research (Empa), Überlandstrasse 129, 8600 Dübendorf, Switzerland

${ }^{e}$ Paul Scherrer Institute (PSI), 5234 Villigen, Switzerland

This document is the accepted manuscript version of the following article:

Defraeye, T., Aregawi, W., Saneinejad, S., Vontobel, P., Lehmann, E., Carmeliet, J., ... Nicolaï, B. (2013). Novel application of neutron radiography to forced convective drying of fruit tissue. Food and Bioprocess Technology, 6(12), 3353-3367. http://doi.org/10.1007/s11947-012-0999-y

\footnotetext{
* Corresponding author. Tel.: +32 (0)16321618; fax: +32 (0)16322966.
}

E-mail address: thijs.defraeye@biw.kuleuven.be 
Defraeye T., Aregawi W., Saneinejad S., Vontobel P., Lehmann E., Carmeliet J., Verboven P., Derome D., Nicolai B. (2013), Novel application of neutron radiography to forced convective drying of fruit tissue, Food and Bioprocess Technology, (DOI:10.1007/s11947-012-0999-y)

Publisher version can be found at: $\underline{\text { http://link.springer.com/article/10.1007\%2Fs11947-012-0999-y }}$

\begin{abstract}
Neutron imaging is a promising technique to study drying processes in food engineering as it is a non-intrusive, nondestructive technique which provides quasi real-time quantitative information of the water loss during drying and of the internal water distribution, at a high spatial and dynamic resolution. Particularly the high sensitivity to water is its main advantage for drying studies, despite the limited accessibility to reactor facilities which produce neutrons. This technique was used to investigate forced convective drying of fruit tissue (pear and apple), placed in a small wind tunnel. Water loss, water distribution in the sample and sample shrinkage were evaluated as a function of time. The water loss, determined quantitatively from neutron radiographs, was underestimated slightly compared to gravimetrical measurements. The overall drying behaviour agreed well with control measurements performed in a climatic chamber and was very similar for both fruit tissues. The corresponding shrinkage behaviour of both tissues was also similar. The large shrinkage, which is characteristic for soft biological materials such as food products, however hindered postprocessing to some extent. From the internal water distribution, the water gradients within the sample, induced by drying, were visualised and were found to predominantly occur at the air-material interface, indicating that the water transport inside the tissue dominated the water loss, instead of the convective exchange with the air flow. Neutron imaging was shown to exhibit unique benefits for studying drying processes of food.
\end{abstract}

\title{
$\underline{\text { Keywords }}$
}

non-destructive; imaging; apple; pear; water; wind tunnel 
Defraeye T., Aregawi W., Saneinejad S., Vontobel P., Lehmann E., Carmeliet J., Verboven P., Derome D., Nicolai B. (2013), Novel application of neutron radiography to forced convective drying of fruit tissue, Food and Bioprocess Technology, (DOI:10.1007/s11947-012-0999-y)

Publisher version can be found at: http://link.springer.com/article/10.1007\%2Fs11947-012-0999-y

\section{$\underline{\text { Introduction }}$}

Drying of foods is a well-known technique used for food preservation (i.e., to extend storage life), for quality enhancement (palatability and digestibility), to facilitate handling of foods (packaging, handling, transportation), to facilitate food processing (e.g., milling) and for sanitation (destruction of microorganisms) (Mujumdar, 2006; Mujumdar \& Law, 2010; Fernandes et al., 2011; Marquez \& De Michelis, 2011). Drying is applied to both raw materials (e.g., fruit, vegetables, tea and coffee, meat and fish, grains and spices) as well as processed products (e.g., instant foods). Drying can, however, reduce the quality of the product due to physical, chemical and biological changes during processing, which can alter food structure and appearance (e.g., colour), but also the taste, mouthfeel and nutritional value of the food (Ratti, 2001). Furthermore, drying is often a rather slow and energy-consuming process. Optimisation of drying processes is thus particularly required to enhance both product quality and processing efficiency, in terms of energy usage and throughput. Such process/product optimisation is especially relevant for high-value foods. Although conventional drying processes are mainly performed convectively (Mujumdar, 2006), which will be the focus of this study, better but more expensive techniques are also available, such as vacuum drying or freeze drying (Ratti, 2001; Mujumdar, 2006).

Apart from numerical modelling, analysis and optimisation of convective drying processes are often performed experimentally. To analyse the water content (liquid and vapour) and water transport within food products, which basically characterise the drying process, both destructive and non-destructive techniques can be used. Non-destructive techniques are preferred as they allow to monitor (preferably quasi real-time) a single sample during the entire drying process. The commonly-used non-destructive techniques are nuclear magnetic resonance (NMR), X-ray radiography (or tomography) and neutron radiography (or tomography). They differ with respect to their spatial and temporal resolution, their capability to detect water qualitatively (dynamic range, i.e. the number of contrast levels) and quantitatively (absolute water content), their accuracy, their accessibility and their ease of use.

NMR has successfully been used to study drying of foods (McCarthy et al., 1991; Hills \& Remigereau, 1997; Verstreken et al., 1998). Its main disadvantages are that the out-of-plane spatial resolution is rather low (resolution in 2D slice $\sim 10-50 \mu \mathrm{m}$ but typical slice thickness $\sim 100-1000 \mu \mathrm{m}$ ), the size of the sample and test setup is limited since they have to be placed inside the coil of the NMR spectrometer and there can be disturbing effects of paramagnetic ions (Balasko et al., 2002). X-ray (micro-)radiography and tomography studies have also been reported in the past for food drying (Leonard et al., 2004, 2005, 2008). With this technique, a high (submicron) resolution can be obtained (e.g., Verboven et al., 2008) and less constraints are present with respect to the test setup and sample size. Note that X-ray radiation can have a damaging effect on the tissue structure of biological materials for long exposure or high beam intensities. The main drawback is however that attenuation of X-rays is related to the electron density of the molecules (e.g., $\mathrm{H}_{2} \mathrm{O}$ ). As water has a quite low number of electrons, comparable to that of most biological materials, the sensitivity of X-rays to water in biological tissue is rather low: differences in contrast are difficult to distinguish, i.e., the dynamic range is quite small (Anderson et al., 2009; Aregawi et al., 2012). In this respect, neutron radiography (or tomography) provides a much higher dynamic range (i.e. the number of contrast levels) since it attenuates significantly for hydrogen, thus water (Anderson et al., 2009). As such, this technique is particularly suitable for water detection and quantification in biological tissues, such as plants or fruits, which are predominantly ( $>80 \%)$ composed of water. Neutron radiograph analysis can provide both overall water content, determined directly from the radiographs, and 
Defraeye T., Aregawi W., Saneinejad S., Vontobel P., Lehmann E., Carmeliet J., Verboven P., Derome D., Nicolai B. (2013), Novel application of neutron radiography to forced convective drying of fruit tissue, Food and Bioprocess Technology, (DOI:10.1007/s11947-012-0999-y)

Publisher version can be found at: http://link.springer.com/article/10.1007\%2Fs11947-012-0999-y

water content distributions. Furthermore, in contrast to X-rays, the test setup can be composed of heavy elements, such as metal (e.g., aluminium), as their attenuation for neutrons is low, which is beneficial for specific experiments (e.g., high temperature or pressure). The main limitations of neutron imaging are the limited accessibility to reactor facilities which produce neutrons and its lower spatial resolution $(\sim 10-50 \mu \mathrm{m})$. In all three techniques an appropriate correction needs to be applied to allow quantitative analysis of the water content (Hassanein et al., 2005), which is not always straightforward for complex setups.

Neutron imaging has already been applied to study water transport in several biological materials, namely for root growth (Menon et al., 2007; Esser et al., 2010) and water transport in flowers (Nakanishi et al., 1999; Matsushima et al., 2009), in leaves (Matsushima et al., 2005a, 2005b), in wood (Nakanishi \& Matsubayashi 1997a; Sedighi-Gilani et al., 2012) and in seeds (Nakanishi \& Matsubayashi, 1997b). For food drying in particular, only one study has been performed (Balasko et al., 2002), to the knowledge of the authors. They used neutron radiography to investigate drying of apple slices qualitatively. With the current techniques however, the water content and the amount of water loss can be quantified accurately with neutron imaging (e.g., Hassanein et al., 2005). As a result, this technique could provide very high resolution data (spatial, temporal and dynamic) on internal water transport during drying. Note that such experiments could also be used to provide detailed data for the validation of numerical drying models (e.g., Veraverbeke et al., 2003b, 2003c; Nguyen et al., 2006b; 2007; Kaya et al., 2006; De Bonis \& Ruocco, 2008; Lamnatou et al., 2009, 2010). Often validation of such models is simply based on measurements of the total sample weight change and/or sample temperatures but the internal water content distribution within the material is usually not evaluated (see Defraeye et al., 2012a).

In this study, forced convective drying of fruit tissue (from pear and apple, placed in a small wind tunnel) has been studied experimentally with neutron radiography. Such a drying process is a coupled (also called conjugate) problem as it involves heat and mass transport in the air and in the material, and is accompanied with large deformations (shrinkage). The main aim of this paper is to evaluate the performance of neutron radiography for: (1) providing quantitative data of the water content and water loss during drying; (2) evaluating the water distribution inside fruit tissue quasi real-time at a high spatial and dynamic resolution; (3) providing detailed experimental data which can be used for validation of numerical models for drying, by using a well-controlled test setup and well-defined boundary conditions. For these purposes, the water loss, water distribution in the sample and sample shrinkage has been evaluated as a function of time. Control measurements in a climatic chamber (without neutron beam, but using the same windtunnel setup) have been performed to confirm the transient water loss of the fruit.

\section{Materials and methods}

\section{Materials}

Two different fruit species were used in the experiments, namely pear and apple. For the neutron experiments, pears (cv. Conference) were picked (September $17^{\text {th }} 2010$ ) at the Experimental Station for Fruit Growing (pcfruit, SintTruiden, Belgium) and stored under controlled atmosphere conditions $\left(2.5 \% \mathrm{O}_{2}, 0.07 \% \mathrm{CO}_{2},-1{ }^{\circ} \mathrm{C}\right)$. The apples (cv. Maigold) were bought in a local grocery shop (Villigen, Switzerland) the day before the actual experiment. The neutron experiments were performed on May $12^{\text {th }}-13^{\text {th }} 2011$. In addition, drying experiments in a climatic chamber (without 
Defraeye T., Aregawi W., Saneinejad S., Vontobel P., Lehmann E., Carmeliet J., Verboven P., Derome D., Nicolai B. (2013), Novel application of neutron radiography to forced convective drying of fruit tissue, Food and Bioprocess Technology, (DOI:10.1007/s11947-012-0999-y)

Publisher version can be found at: $\underline{\text { http://link.springer.com/article/10.1007\%2Fs11947-012-0999-y }}$

neutron beam, but with the same experimental setup) were performed in a later stage (March $9^{\text {th }}-15^{\text {th }} 2012$ ) for both fruits. For these experiments, both pear (cv. Conference) and apple (cv. Braeburn) fruits were bought in a local warehouse (Zurich, Switzerland) the day before the actual experiment. Pear and apple fruit are typically composed of water ( 70-80\%), air ( 5-30\%), and biological material ( $\sim 10-15 \%$, mainly carbohydrates and fiber with minor fractions of protein, lipids and organic acids).

\section{$\underline{\text { Experimental setup }}$}

An open-circuit wind-tunnel setup was designed to subject a drying sample to controlled air flow conditions while imaging its water content distribution. This micro wind tunnel, shown in Figure 1, was fabricated with polymethylmethacrylate (PMMA) with the exception of the test section which was made out of pure aluminium, as this material is very transparent for neutrons. Air flow is produced by a small axial fan of $50 \mathrm{~mm}$ diameter. After going through a diffusing section, with increasing cross section, the air flow passes through a honeycomb made of $5 \mathrm{~mm}$ wide cells and a two-dimensional contraction (contraction ratio $=5$ ), which provide flow conditioning. The channel test section is $10 \mathrm{~mm}$ high and has a width ( $z$-axis) to height ( $y$-axis) ratio of 7 , which is the minimum ratio to have quasi two-dimensional channel flow (Dean, 1978). By fan control, the centreline air speed $\left(U_{c l}\right)$ at the inlet (location IP) of the channel (height $H=10 \mathrm{~mm}$ ) can be varied from $0.28 \mathrm{~m} \mathrm{~s}^{-1}$ to $4.2 \mathrm{~m} \mathrm{~s}^{-1}$ corresponding to Reynolds numbers $(R e)$ of 200 to 2900 (based on $U_{c l}$ and $H$ ). This setup can thus produce both laminar and turbulent flow conditions. Below the channel, samples of maximum $90 \mathrm{~mm}$ ( $x$-axis) x $50 \mathrm{~mm}$ (y-axis) cross section can be fitted in a sample box. The thickness of the sample ( $z$-axis) is chosen in terms of its attenuation for the type of radiation used. The rest of the volume in the sample box is filled with insulation material, in this study extruded polystyrene (XPS). This wind-tunnel setup was specially designed for experiments with X-ray and neutron radiography, which thus required a limited overall size (length and width). Despite these small dimensions, the flow in the channel was found to be quasi two dimensional but slightly developing, as mentioned below.

The mean air speed and turbulence intensity profiles in the centre of the channel at the inlet (location IP) were measured by means of particle image velocimetry (PIV). PIV is a non-intrusive flow measuring technique, where the displacement of small (ideally massless) tracer particles, which are seeded in the air flow, is measured. These displacements and the corresponding velocity vectors are determined by illuminating the particles within a 2D light sheet by a pulsed laser combined with appropriate optics, after which image correlation is performed. Information on PIV and the PIV system used in the experiments can be found in Defraeye (2011). The uncertainty on the mean air speed was estimated to be about $2 \%$. For centreline air speeds above $1.8 \mathrm{~m} \mathrm{~s}^{-1}\left(\operatorname{Re}=1200\right.$, based on $U_{c l}$ and $\left.H\right)$, the air speed and turbulence intensity profiles were found to become quasi independent of the Reynolds number, indicating turbulent flow. This Reynolds number agrees quite well with the minimal Reynolds number of 1300 (based on the bulk air speed and channel height) to have turbulent flow in a two-dimensional channel, stated by Dean (1978). The profiles in the centreplane of the channel $(z=0)$ are shown in Figure 2 for $U_{c l}=2.34 \mathrm{~m} \mathrm{~s}^{-1}\left(R e=1600\right.$, based on $U_{c l}$ and $\left.H\right)$ and are quite uniform and symmetric. The experiments reported in this study were all performed at this air speed. From measurements in other vertical planes ( $z$-direction), the flow in the channel was found to be quasi two-dimensional (differences with centreplane values $<10 \%$ ). Furthermore, the relative humidity $(\mathrm{RH})$ and temperature of the incoming air were monitored by a calibrated RH sensor (accuracy $0.1^{\circ} \mathrm{C}$ and $2 \%$ for temperature and RH, respectively). This test 
Defraeye T., Aregawi W., Saneinejad S., Vontobel P., Lehmann E., Carmeliet J., Verboven P., Derome D., Nicolai B. (2013), Novel application of neutron radiography to forced convective drying of fruit tissue, Food and Bioprocess Technology. (DOI:10.1007/s11947-012-0999-y)

Publisher version can be found at: http://link.springer.com/article/10.1007\%2Fs11947-012-0999-y

setup was used for two types of experiments, namely neutron experiments and experiments in a climatic chamber (without neutron beam).

The fruit samples (average length $\mathrm{x}$ height $\mathrm{x}$ width $(x, y, z) \sim 40 \times 30 \times 10 \mathrm{~mm}^{3}$, exact dimensions are specified further below, without skin) were cut from fresh fruits a few minutes before the actual experiment and were weighed to determine their initial weight $\left(m_{i n i}, \mathrm{~kg}\right)$. These samples were mounted in the centre of the channel, flush with the channel wall (i.e. at the same height, $y$-direction, see Figure 1). A small sample width was chosen to minimise edge effects from the wind-tunnel side walls. The samples were thermally insulated (with extruded polystyrene, XPS) and were made impermeable for water on all surfaces (i.e., by wrapping it in aluminium foil), except for the surface interfacing the channel flow. After mounting the sample, the fan was switched on, indicating the start of the experiment. Note that for the neutron experiments, a reference neutron radiograph of the sample, at its initial state and in place within the setup (without airflow), was taken before switching on the fan. The average time interval between cutting the samples and this first neutron image was at least 15 minutes, in part since the beamline had to be closed and made secure. For the neutron experiments, the weight of the sample was only measured before mounting $\left(m_{i n i}\right)$ and after the measurements $\left(m_{e n d}\right)$, whereas for the experiments in the climatic chamber, the weight of the wind tunnel (thus of the sample) was also continuously monitored by placing the setup on a balance (accuracy $0.01 \mathrm{~g}$ ). These experiments aimed to verify the drying process in the neutron beam, and to provide a continuous sample weight change by gravimetrical measurements, for comparison with the neutron results.

Convective drying experiment by neutron radiography

\section{Neutron radiography facility}

The imaging facilities of the Neutron Transmission Radiography beamline (NEUTRA http://www.psi.ch/sinq/neutra) at the Paul Scherrer Institute (PSI, Villigen, Switzerland) were used for detailed visualization and quantification of transient water transport in pear and apple tissues. Neutron radiography at the NEUTRA beamline station relies on a neutron beam within the thermal spectrum, with a most probable energy level of about $25 \mathrm{meV}$ (Lehmann et al., 2001). Figure 3 shows a schematic overview of the neutron beamline with the test setup. The detector consists of a scintillatorCCD camera system, with a total field of view of $85 \times 85 \mathrm{~mm}^{2}$ for the present experiments. The scintillator, made of $100 \mu \mathrm{m}$ thick zinc sulfide doped with ${ }^{6} \mathrm{Li}$ as the neutron absorbing agent, converts the neutron signals into visible light photons. The photons are then led via a mirror onto a cooled 16-bit CCD camera ( 2048 x 2048 pixels). Note that 2 × 2 binning of the pixels was applied, resulting in 1024 x 1024 binned pixels, by which the attained spatial resolution was $83 \mu \mathrm{m}$ for the present experiments. Note that a higher resolution can be obtained with neutron imaging $(\sim 30 \mu \mathrm{m}$ at NEUTRA), however requiring a smaller field of view.

\section{Neutron experiments}

The experimental setup, as placed in the NEUTRA beamline, is shown in Figure 3, both schematically and with a picture. The dimensions of the apple and pear samples are given in Table 1, together with their initial water content $\left(w_{i n i}, \mathrm{~kg} \mathrm{~m}^{-3}\right)$. This water content was determined gravimetrically as the ratio of the total amount of water in the fruit sample (initial weight $\left(m_{i n i}\right)$ - dry weight after oven drying the sample $\left(\right.$ at $\left.60^{\circ} \mathrm{C}\right)$ until it was completely dry $\left.\left(m_{d r y}\right)\right)$ to the initial sample volume (see Table 1). After the sample was cut, weighed $\left(m_{i n i}\right)$ and mounted in the wind-tunnel setup, a 
Defraeye T., Aregawi W., Saneinejad S., Vontobel P., Lehmann E., Carmeliet J., Verboven P., Derome D., Nicolai B. (2013), Novel application of neutron radiography to forced convective drying of fruit tissue, Food and Bioprocess Technology. (DOI:10.1007/s11947-012-0999-y)

Publisher version can be found at: http://link.springer.com/article/10.1007\%2Fs11947-012-0999-y

reference neutron radiograph of the sample, at its initial state and in place within the setup (without airflow), was obtained (at least 15 minutes after cutting). Then the drying experiment was started. In the neutron experiments, the sample was dried for a period of about $12 \mathrm{~h}$ for pear and $8 \mathrm{~h}$ for apple. During drying, neutron radiographies of the sample were acquired at a time interval of less than $5 \mathrm{~min}$. The exposure time of the radiographies was 8 seconds. The conditions of the air in the NEUTRA beamline varied to some extent with time but were quite stable over one experiment. For the pear, the mean temperature was $24.6^{\circ} \mathrm{C}$ (standard deviation $=0.3^{\circ} \mathrm{C}$ ) and the mean relative humidity was $35 \%$ (standard deviation $=3.9 \%$ ). For the apple, the mean temperature was $25.1{ }^{\circ} \mathrm{C}$ (standard deviation $=$ $0.2^{\circ} \mathrm{C}$ ) and the mean relative humidity was $28.1 \%$ (standard deviation $=2.2 \%$ ). At the end of the experiment, the sample was weighed $\left(m_{\text {end }}\right)$ to determine the total sample water loss during the experiment $\left(m_{\text {ini }}-m_{\text {end }}\right)$.

\section{Quantification of water loss by analysis of neutron radiographs}

\section{Water loss}

Neutron radiography is based on intensity measurements of a neutron beam transmitted through an object (Figure 3). The intensity of the transmitted monochromatic beam $(I)$ at a specific time $(t)$ can be described with the Beer-Lambert law:

$$
I(t)=I_{\mathrm{O}} e^{-\mu \cdot z}
$$

where $I_{0}$ is the intensity of the incident neutron beam, $z$ is the thickness of the object along the beam direction $(\mathrm{m})$ and $\mu$ is the effective attenuation coefficient for neutrons $\left(\mathrm{m}^{-1}\right)$. For a compound material like fruit tissue or water, the attenuation coefficients of the individual elements (mainly hydrogen, but also oxygen, carbon, etc.) determine the total attenuation. The composition of the tested fruit sample was simplified by assuming it to consist of fruit tissue and water, using a bi-layer approximation (e.g., Sedighi-Gilani et al., 2012): the effect of the remaining water present in the fruit tissue on the neutron beam attenuation, at time $t$ during drying, was considered equivalent to the effect of a water layer with thickness $z_{w}$ added to the dry fruit sample. In addition, the neutron beam was also attenuated by the wind-tunnel test setup (XPS insulation and aluminium). Implementing this in Eq.(1) results in:

$$
I(t)=I_{0} e^{-\left(\mu_{F T} z_{F T}+\mu_{T S} z_{T S}+\mu_{w} z_{w}\right)}
$$

where the subscript $F T$ refers to the (dry) fruit tissue, $T S$ to the test setup and $w$ to the water (liquid and vapour). At a certain time $t$ during the experiment, the change in the beam intensity, with respect to the initial state, is a result from the time-dependent change of the water content, i.e., from the reduction of the "effective" water layer when drying. Assuming fruit tissue shrinkage in the direction along the neutron beam had a negligible effect on beam attenuation, Eq.(2) can be written as:

$$
I(t)=I_{0} e^{-\left(\mu_{F T} z_{F T}+\mu_{T S} z_{T S}+\mu_{w} z_{w}(t)\right)}=I_{0} e^{-\left(\mu_{F T} z_{F T}+\mu_{T S} z_{T S}+\mu_{w}\left(z_{w}\left(t_{0}\right)+\Delta z_{w}(t)\right)\right)}
$$

where $t_{0}$ is the time of the first neutron image after the start of the drying experiment, $z_{w}\left(t_{0}\right)$ is the initial water thickness, $\Delta z_{w}(t)$ is the reduction in water thickness at time $t$ due to the water removal from the sample during drying, and has a 
Defraeye T., Aregawi W., Saneinejad S., Vontobel P., Lehmann E., Carmeliet J., Verboven P., Derome D., Nicolai B. (2013), Novel application of neutron radiography to forced convective drying of fruit tissue, Food and Bioprocess Technology. (DOI:10.1007/s11947-012-0999-y)

Publisher version can be found at: http://link.springer.com/article/10.1007\%2Fs11947-012-0999-y

negative value. Note that the transmitted beam intensity $(I)$ increases with time as the amount of water in the sample decreased. Eq.(3) can be solved to the water thickness:

$z_{w}(t)=z_{w}\left(t_{0}\right)+\Delta z_{w}(t)=-\frac{1}{\mu_{w}}\left[\ln \left(\frac{I(t)}{I_{0}}\right)+\mu_{F T} z_{F T}+\mu_{T S} z_{T S}\right]$

With Eq.(4), the water thickness $\left(z_{w}(t)\right)$ can thus be determined quantitatively using these three attenuation coefficients. However, the specific attenuation of both test setup and fruit tissue are not known, as no measurement was performed towards that goal. Furthermore, scattering corrections of the neutron radiographs (see later on in this section) could not be made for both test setup and fruit tissue, due to lack of information on the scattering properties of these materials. Thereby, directly determining the absolute value of the water thickness of the actual water layer (thus the sample water content) from the neutron radiographs was not possible in the present study since the obtained water thicknesses inherently include the influence of the fruit tissue and the test setup (Eq.(4)). Especially XPS (chemical formula: $\left.\left(\mathrm{C}_{8} \mathrm{H}_{8}\right)_{\mathrm{n}}\right)$ is believed to have the most important contribution to the water thickness due to the presence of hydrogen and its rather large thickness. However, as the change in neutron beam attenuation (and scattering) in this drying experiment can be assumed to be entirely due to the change of water content in the sample, the relative change in water thickness with time $\left(\Delta z_{w}(t)\right.$, thus sample water loss) could be determined by relating all images to the first image:

$I(t)=I_{0} e^{-\left(\mu_{F T} z_{F T}+\mu_{T S} z_{T S}+\mu_{w}\left(z_{w}\left(t_{0}\right)+\Delta z_{w}(t)\right)\right)}=I\left(t_{i n i}\right) e^{-\left(\mu_{w} \Delta z_{w}(t)\right)}$

with $I\left(t_{\text {ini }}\right)=I_{0} e^{-\left(\mu_{F T} z_{F T}+\mu_{T S} z_{T S}+\mu_{w}\left(z_{w}\left(t_{0}\right)\right)\right)}$

$I\left(t_{i n i}\right)$ is the intensity of the neutron beam for the initial, freshly cut fruit sample, i.e., at the start of the neutron experiments, and was lower than $I(t)$, due to the higher water content (exponent to $\left.-\left(\mu_{w} \Delta z_{w}(t)\right)>1\right)$. Solving Eq.(5) for the change in water thickness $\left(\Delta z_{w}(t)<0\right)$ yields:

$\Delta z_{w}(t)=-\frac{1}{\mu_{w}} \ln \left(\frac{I(t)}{I\left(t_{i n i}\right)}\right)$

Multiplying this reduction in water thickness with the density of water $\left(\rho_{w}, \mathrm{~kg} \mathrm{~m}^{-3}\right)$ gives the change in water mass thickness over time $\left(\Delta Z_{w}(t), \mathrm{kg} \mathrm{m}^{-2}\right)$ :

$\Delta Z_{w}(t)=\rho_{w} \Delta z_{w}(t)$

Dividing $\Delta Z_{w}$ by the total (initial) specimen thickness $\left(z_{t o t, i n i}=z_{w, i n i}+z_{F T, i n i}\right)$ gives the change in water content of the sample over time $\left(\Delta w(t), \mathrm{kg} \mathrm{m}^{-3}\right)$ :

$$
\Delta w(t)=\frac{\Delta Z_{w}(t)}{z_{\text {tot, ini }}}=\rho_{w} \frac{\Delta z_{w}(t)}{z_{\text {tot, ini }}}=-\frac{\rho_{w}}{\mu_{w} z_{\text {tot, ini }}} \ln \left(\frac{I(t)}{I\left(t_{\text {ini }}\right)}\right)
$$


Defraeye T., Aregawi W., Saneinejad S., Vontobel P., Lehmann E., Carmeliet J., Verboven P., Derome D., Nicolai B. (2013), Novel application of neutron radiography to forced convective drying of fruit tissue, Food and Bioprocess Technology. (DOI:10.1007/s11947-012-0999-y)

Publisher version can be found at: http://link.springer.com/article/10.1007\%2Fs11947-012-0999-y

The initial thickness was taken here $\left(z_{\text {tot,ini }}\right)$ since the sample shrinkage in the direction of the neutron beam could not be determined from radiographs. The water mass thickness $Z_{w}(t)$ and water content $w(t)$ at each point in time can then be determined by scaling with the initial water content ( $w_{i n i}$, see section on neutron experiments below) :

$$
\begin{aligned}
& Z_{w}(t)=w_{\text {ini }} z_{\text {tot }, \text { ini }}+\Delta Z_{w}(t) \\
& w(t)=w_{\text {ini }}+\Delta w(t)
\end{aligned}
$$

Note that a constant sample thickness $\left(z_{t o t, i n i}\right)$ over time was assumed in Eq.(10), as its change was unknown and strongly variable in space. Since the thickness actually varied with time (due to volume changes from shrinkage), the obtained water content becomes less realistic as the drying process proceeds, by which it makes more sense to use the water mass thickness. For a monochromatic neutron beam, Eqs.(9-10) allow plotting the spatial distribution of the water mass thickness and water content at different times.

The total water loss of the sample with time $\left(\Delta m_{w, t o t}(t)\right)$ can be calculated as:

$$
\Delta m_{w, t o t}(t)=\Delta Z_{w, a v g}(t) A_{f}
$$

where $A_{f}$ is the frontal area of the sample as seen in the radiograph $\left(\mathrm{m}^{2}\right)$ and $\Delta Z_{w, \text { avg }}(t)$ is the surface-averaged value (over all pixels) of the water mass thickness change $\left(\Delta Z_{w}\right)$ over $A_{f}$. Note that this frontal area decreased during drying. The frontal area was determined manually, but the resulting areas agreed well with results from the edge detection algorithm from ImageJ software (Abramoff et al., 2004). Due to this manual edge detection, not all neutron images were processed, but only images at about every $30 \mathrm{~min}$. In this study, obtaining the local (pixelwise) water loss (or change in water content) by means of Eqs.(9-10) was not straightforward since the sample shrunk significantly during drying, by which the $(x, y)$ coordinates of a certain point in the sample changed over time. In case of small deformations, the radiographs can be registered against the first image of the experiment, allowing local comparison of water content (e.g., Sedighi-Gilani et al., 2012). Due to the large deformations seen in this experiment, such reconstruction was not pursued and explicitly monitoring of local content was not performed. In the results section (local water loss), a simplified way of obtaining the local water content is explained.

\section{Image correction}

Prior to quantitative analysis (e.g., from Eqs.(9-10)), each raw neutron radiograph needs to be corrected. These corrections use standard procedures common to all radiation transmission-based imaging methods, and include:

1. Dark current correction for the background noise of the CCD camera, performed by subtracting (pixelwise) the radiograph acquired in absence of a neutron beam from each radiograph of the sample.

2. Intensity correction for fluctuations of the incident beam, performed by averaging the beam variation in an area of the radiograph outside the sample area, and applying this averaged correction factor to each pixel.

3. Flat field correction for eliminating spatial inhomogenities in the beam (and detector) from the radiographs, performed by correcting (pixelwise) each radiograph with a radiograph with an open beam, without the setup. 
Publisher version can be found at: $\underline{\text { http://link.springer.com/article/10.1007\%2Fs11947-012-0999-y }}$

4. Black body correction for removing the neutron signal coming from scattering by the overall experimental configuration and environment, performed by subtracting a constant value from each radiograph of the sample. For this constant value, the average value of the beam variation in the field of view is taken for a radiograph acquired when the sample is shielded with boronated polyethylene blocks.

5. Sample scattering correction for neutrons that are scattered at small angles by the atoms of the fruit, tissue, water or test setup. Due to lack of information on the scattering properties of the fruit tissue and test setup, the scattering correction was performed assuming water as the only scattering material.

6. Taking into account the beam polychromatic energy spectrum, as Eqs. (1-11) are derived for a monochromatic neutron beam.

To perform these corrections, the Quantitative Neutron Imaging (QNI) algorithm, developed by Hassanein (2006), was used. Especially the scattering correction is required for increased accuracy. Uncorrected radiographs result in an underestimation of the water content, up to $50 \%$, compared with corrected radiographs, and this error increases with increasing water thickness. In this study, the water thickness of the samples was quite high $(\sim 7-8 \mathrm{~mm})$, resulting in a highly attenuated neutron beam in addition to the presence of scattering, by which a scattering correction should be definitely applied. The QNI scattering correction algorithm is based on the iterative reconstruction of the measured image by overlapping point scattered functions calculated by means of Monte-Carlo simulation. By means of the QNI correction, Hassanein et al. (2005) found errors in water thickness below 5\% for water thicknesses up to $5 \mathrm{~mm}$. The water mass thickness $\left(Z_{w}(t)\right)$ can be estimated as a single variable from QNI. Although its absolute value from QNI is not correct, due to the influence of the test setup and fruit tissue (discussed in the first part of the section on quantification of water loss by analysis of neutron radiographs), it can be used to calculate the change in water mass thickness $\left(\Delta Z_{w}(t)\right)$ during drying via Eq.(7), and can then be calculated back to the actual $Z_{w}(t)$ via Eq.(9).

The resolution in water content (dynamic range) is defined as the water content corresponding to one grayscale difference from the incident neutron beam intensity (see Eq.(8)):

$$
R=-\frac{\rho_{w}}{z_{t o t} \mu_{w}} \ln \left(\frac{I_{0}-1}{I_{0}}\right)
$$

Thus, the resolution depends on the density and the attenuation coefficient of water, the thickness of the sample and the neutron radiograph intensity, $I_{0}$. In this study, the dynamic resolution was about $0.02 \mathrm{~kg} \mathrm{~m}^{-3}$, which is high, compared to X-ray radiography.

\section{Error estimation}

Due to the complexity of the ensemble of image corrections applied on the raw neutron radiographs, it is rather difficult to estimate the propagation of errors related to the experimental setup and the image correction procedures on the resulting water thickness or moisture content. Therefore, the experimental errors reported in this study were based on the study of Hassenein et al. (2005), where a detailed evaluation was made on the accuracy of the NEUTRA beamline, in combination with the QNI algorithm, for the prediction of water thickness. Here, errors in water thickness $\left(z_{w}\right)$ below $5 \%$ were found for water thicknesses up to $5 \mathrm{~mm}$. As a conservative error estimate for the present study, an error of $5 \%$ 
Defraeye T., Aregawi W., Saneinejad S., Vontobel P., Lehmann E., Carmeliet J., Verboven P., Derome D., Nicolai B. (2013), Novel application of neutron radiography to forced convective drying of fruit tissue, Food and Bioprocess Technology (DOI:10.1007/s11947-012-0999-y)

Publisher version can be found at: http://link.springer.com/article/10.1007\%2Fs11947-012-0999-y

on $z_{w}$ (Eq.(4)) was assumed. This relative error was assumed to propagate directly into the water content ( $\left.w, \mathrm{Eq} .(10)\right)$, as all other error sources were negligible. For the error on the total water loss of the sample ( $\Delta m_{w, t o t}$ Eq.(11)), the error on $\Delta Z_{w, a v g}$ (also $5 \%$, from $\Delta z_{w}$ ) and on $A_{f}$ had to be combined. The error on $A_{f}$ was estimated to be $1 \%$, which is a conservative estimate. The resulting relative error on $\Delta m_{w, t o t}$ is (multiplication): $\delta\left(\Delta m_{w, \text { tot }}\right)=\delta\left(\Delta Z_{w, \text { avg }}\right)+\delta\left(A_{f}\right)=6 \%$. These errors are used to represent the error bars in the results section.

Performing repetitions of the neutron experiments would be advised, amongst others to identify the repeatability of the experiments and to allow more detailed statistical analysis. However, the beamtime at the neutron facility was limited, by which no replicate experiments for both fruit tissues (pear and apple) could be performed here, and consequently repeatability could not be verified directly for the neutron experiments. In order to still check the repeatability, experiments in a climatic chamber were performed, using the same test setup and under similar climatic conditions, in order to confirm if the transient water loss of the fruit could be reproduced. Since intersample variability is inherently present, the aim of this intercomparison was to identify if the same trends could be observed, rather than to exactly match both experiments. These experiments are discussed in the next section.

\section{Convective drying experiment in climatic chamber}

Results from experiments on both fruits at NEUTRA are compared with two similar drying experiments (i.e. using the same wind-tunnel setup) while putting the wind tunnel in a climatic chamber (without neutron beam) to verify the obtained results of the neutron experiment, particularly with respect to the water loss as a function of time, and their reproducibility. For this purpose, the wind-tunnel test setup was placed in a climatic chamber (temperature $=23.3^{\circ} \mathrm{C}$, relative humidity $=30 \%$ ), i.e. approximately the same conditions as found in the NEUTRA beamline (see section on neutron experiments). The samples were prepared in the same way as for the neutron experiments, and also $m_{i n i}, m_{d r y}$ and $m_{\text {end }}$ were determined in a similar way. The weight of the wind tunnel, thus the sample water loss, was continuously monitored during drying (accuracy $0.01 \mathrm{~g}$ ). The sample was dried for a period of about $70 \mathrm{~h}$ for both pear and apple. Such a long drying time was chosen to evaluate the drying behaviour of the tissue over a longer period, which was not possible in the neutron experiments due to time constraints. The initial dimensions of the apple and pear samples are given in Table 1, together with the initial water content.

\section{$\underline{\text { Results and discussion }}$}

\section{$\underline{\text { Total water loss }}$}

In this section, the total water loss from the two fruit samples is evaluated. This is done in three ways: (1) from the neutron radiographs, by determining the water loss according to Eq.(11); (2) from the sample weight at the start $\left(m_{\text {ini }}\right)$ and end $\left(m_{\text {end }}\right)$ of the neutron experiments; (3) from the experiments in the climatic chamber, where the sample weight was continuously monitored. Note that the latter only serves as a relative comparison with the neutron experiments since the samples were different in both cases. A comparison between these different water losses, as a function of time, is presented in Figure 4, for both pear and apple. In Figure 5, the water loss of pear is compared with that of apple, based on neutron radiography on the one hand, and experiments in the climatic chamber on the other hand. The drying behaviour of the fruit samples over a longer time span, from the experiments in the climatic chamber, is shown in Figure 6. Due to time restrictions, such long experiments were not possible at the neutron beamline. 
Defraeye T., Aregawi W., Saneinejad S., Vontobel P., Lehmann E., Carmeliet J., Verboven P., Derome D., Nicolai B. (2013), Novel application of neutron radiography to forced convective drying of fruit tissue, Food and Bioprocess Technology. (DOI:10.1007/s11947-012-0999-y)

Publisher version can be found at: $\underline{\text { http://link.springer.com/article/10.1007\%2Fs11947-012-0999-y }}$

The water loss predicted from the neutron radiographs $\left(\Delta m_{w, t o t}(t)\right.$, Eq.(11)) agrees quite well for both pear and apple, when comparing both fruit (Figure 5). They both show a non-linear drying behaviour, which is confirmed by the experiments in the climatic chamber. However, for both fruit samples, the neutron radiographs underpredict the total amount of water lost from the sample up to $20 \%-30 \%$ (Figure 4$)$, when compared to the sample water loss $\left(m_{\text {ini }}-m_{\text {end }}\right)$ from the neutron experiments (i.e., not those from the climatic chamber). Several possible reasons could be given for this mismatch in water loss:

- Water was lost from the sample due to evaporation during the period between the measurement of the initial weight (right after cutting) and the actual start of the experiment (first neutron radiography), as well as between the end of the experiment (last neutron radiography) and the measurement of the end weight. This resulted in a sample water loss which cannot be detected from the neutron radiographs, and could explain, in part, the underestimation of the water loss from the neutron radiographs. This water loss was difficult to avoid as it was inherent to the experimental procedure. Although difficult to quantify, it was estimated to be at least $0.1 \mathrm{~g}$.

- Since the sample shrunk, the edges needed to be redetected in each image to determine the total (average) amount of water in the sample (Eq.(11)). This edge detection became more difficult as the sample dried, due to lower contrast, and could also cause errors in $A_{f}$, but also in $\Delta Z_{w, \text { avg }}$ and consequently in $\Delta m_{w, t o t}$ (Eq.(11)). Although these errors were estimated to be rather limited, they also contribute to the overall mismatch in water loss.

- The accuracy of the scattering correction, by means of QNI, is dependent on the water mass thickness in the sample (Hassanein et al., 2005). As the water mass thickness changes over time, especially at the top of the sample, the accuracy of the scattering correction (thus of the resulting water loss) can also change during drying.

It is important to note that, although the absolute water content of the samples could not be obtained in this experiment for reasons mentioned above, the water loss during drying $\left(\Delta m_{w, t o t}\right)$ should, after correction (with QNI), provide quantitatively reliable results, as the only change over time in the radiographs was the change in water content of the sample. The reasons mentioned in the previous paragraph explained possible errors introduced in this quantitative assessment. As discussed in relation with Eq.(4), a quantification of the water content requires that: (1) information on the water thickness of the (dry) fruit tissue and the test setup is known, which could be obtained by evaluating reference samples with the same thickness (or the test setup without sample); (2) a scattering correction for the fruit tissue and the test setup is performed. Now their scattering effect on the neutron radiographs is, although the same for each radiograph, unknown, but required for quantitative analysis of the water content. Now, all scattering corrections are based on the scattering properties of water (see section on quantification of water loss by analysis of neutron radiographs). Note however that for biological materials like fruit, which are predominantly composed of water, attenuation (and scattering) will be mainly related to water (Nakanishi et al., 1999), compared to the hydrogen present in the fruit tissue.

Although apple and pear dry in a very similar way, apple seems to dry a bit faster in the neutron experiment. In the climatic chamber, pear dries faster than apple at the start, and after a long period (Figure 6). Given that the flow field 
Defraeye T., Aregawi W., Saneinejad S., Vontobel P., Lehmann E., Carmeliet J., Verboven P., Derome D., Nicolai B. (2013), Novel application of neutron radiography to forced convective drying of fruit tissue, Food and Bioprocess Technology. (DOI:10.1007/s11947-012-0999-y)

Publisher version can be found at: $\underline{\text { http://link.springer.com/article/10.1007\%2Fs11947-012-0999-y }}$

and air flow conditions in both neutron experiments are about the same, the difference in drying rate (water loss) should be related to internal water transport in the fruit, thus differences in diffusion coefficients between pear and apple. The diffusion coefficients of pear and apple are of the same magnitude (see Nguyen et al. (2006a) for pear and Veraverbeke et al. (2003a) for apple, see Table 2). The similarity between the drying rates of both fruits is thus in agreement with their expected internal water transport properties. Note however that these coefficients are very species-dependent and also subject to a large intersample variability. Furthermore, diffusion coefficients are dependent on the temperature, shelf life and on the tissue type (inner or outer tissue, e.g., Nguyen et al., 2006a) and are most likely also dependent on the water content.

\section{Local water loss}

In this section, the local water loss and distribution (thus transport) in the samples during drying is investigated. For this purpose, the corrected (QNI) neutron radiographs of water mass thickness $\left(Z_{w}\right)$ were converted pixelwise to water content ( $w)$ by:

$$
w(t)=\frac{Z_{w}(t)}{z_{\text {tot,ini }}}=\rho_{w} \frac{z_{w}(t)}{z_{\text {tot, ini }}}
$$

As the absolute values of the water mass thickness, or water content $(w(t))$, from QNI were not correct, the corrected neutron radiographs needed also to be adjusted so their water content represented the actual water content. This was done in a simplified way by matching the overall water content of the sample (surface-averaged, $w_{\text {avg }}(t=0)=$ $\left.Z_{w, \text { avg }}(t=0) / z_{\text {tot,ini}}\right)$ at the start of the experiment (from neutron radiographs) to $w_{\text {ini }}$, and by adjusting the local water contents from the radiographs accordingly pixelwise, at each time. Note that this is a rather simplified method, as a correction based on surface-averaged values is performed, where the water content (thus also the thickness of the fruit tissue) can vary locally (pixelwise). The internal distribution of this water content is represented in Figure 7 and Figure 8 at different times for both pear and apple fruit. Figure 8 provides a close-up of the upper part of the sample, i.e. at the air-material interface. In Figure 9, corresponding water content profiles in the vertical centreline of the sample $(x=20$ $\mathrm{mm}$ ) are shown, which are smoothed to some extent (averaged) over several pixels to increase clarity. Note from Figure 7 and Figure 9 that the initial water content is slightly higher at the top of the sample $(y \approx 0 \mathrm{~mm})$, and also remains slightly higher than in the rest of the sample throughout the drying process..

The drying behaviour of both species is quite similar. Furthermore, the water gradients within the sample, induced by drying, are limited: only close to the air-material interface (first few millimetres, $y$-direction), drier tissue is found. At this interface, large gradients are present (Figure 9). The differences in drying rate (water distribution) and in shrinkage between the leading and trailing edge zones of the sample are also limited. This fact, and the fact that the water content remains quasi constant within the samples (i.e., uniformly decreasing), even for forced convective drying, indicate that water transport within the fruit tissue mainly dominates the drying rate, and not the convective (air flow) conditions, as they would induce a higher drying rate at the leading edge. Similar results were obtained by Nguyen et al. (2006b) through MRI experiments. After the experiments, it was also noticed (by cutting the fruit tissue), that both fruits actually had a very thin dry tissue layer at their surface, below which very moist tissue was present. This thin tissue layer acts as the main resistance to water loss, which limits dehydration of the inner tissue. In analogy with general 
Defraeye T., Aregawi W., Saneinejad S., Vontobel P., Lehmann E., Carmeliet J., Verboven P., Derome D., Nicolai B. (2013), Novel application of neutron radiography to forced convective drying of fruit tissue, Food and Bioprocess Technology. (DOI:10.1007/s11947-012-0999-y)

Publisher version can be found at: http://link.springer.com/article/10.1007\%2Fs11947-012-0999-y

drying processes (e.g., Defraeye et al., 2012b), this indicates that the decreasing drying rate period, where the material is dry at the interface, sets in quite quickly and that the constant drying rate period, where air-flow conditions dominate the drying rate, is very short. This also indicates again that effective diffusion coefficients of the tissue must be strongly dependent on water content.

\section{$\underline{\text { Shrinkage }}$}

In this section, the shrinkage of the samples is investigated, based on the neutron radiographs. Since only 2D information on the shrinkage was available, i.e., the radiographs, only the 2D surface area change could be evaluated. Note however that the samples also shrunk in the direction of the neutron beam (z-direction in Figure 1), which could not be quantified in these experiments. Neutron tomography could alleviate this problem as it allows for an evaluation of the volumetric shrinkage. Note however that the duration of a single tomography $(\sim 1 \mathrm{~h})$ is probably too long for most forced convective drying experiments of fruit, since considerable sample shrinkage will be present during such a tomography. For all cases in this study, the actual volumetric shrinkage was larger than that based on the 2D surface area change. The contours of the change in sample surface area with time during drying are shown in Figure 10, as determined from the neutron radiographs for pear and apple fruit. The corresponding percentage change in sample surface area, as a function of time, is presented in Figure 11.

In this study, deformation of fruit tissue is considered to be large if the mechanical behaviour of the material cannot be described anymore by linear elasticity theory, thus implying deformations higher than 1-2\% (Misra et al., 2008). The deformations found in the present experiment clearly became large quite fast after the start of the experiment. The shrinkage behaviour of both samples agrees quite well, both with respect to the percentage change in sample surface area over time as to the shrinkage profiles. Note that the drying time of apple (8h) was lower than for pear (12h). For pear, shrinkage can even be seen at the bottom of the sample, which is assumed not to be driven by local drying but by mechanical reaction of the sample to the shrinkage on the top of the sample, i.e., at the air-material interface. The shrinkage behaviour ( $y$-direction) of the entire samples, and at the leading and trailing edge zones, are also very similar, thus confirming that convective transfer is not dominating water transport.

\section{Conclusions}

In this study, forced convective drying of fruit tissue (pear and apple) was studied experimentally with neutron radiography. For this purpose, a small wind-tunnel test setup was used, and water loss, water distribution in the sample and sample shrinkage were evaluated as a function of time. It was not straightforward to quantify the (local) absolute values of the water content directly from the neutron radiographs, mainly due to the complexity of the setup. Ways to alleviate this in a simplified manner, or in future experiments were discussed. However, the water loss could be determined quantitatively by comparing differences between radiographs. Postprocessing was hindered to some extent by the large shrinkage of the samples, which is characteristic for biological materials such as foods.

The drying behaviour of both fruit samples was very similar, when comparing these species. For each fruit, the drying behaviour from neutron radiography agreed well with control measurements performed in a climatic chamber (without neutron beam but using the same wind-tunnel setup). The calculated water loss, obtained from neutron radiographs, was slightly smaller than the water loss measured gravimetrically. From the internal water distribution, the water gradients 
Defraeye T., Aregawi W., Saneinejad S., Vontobel P., Lehmann E., Carmeliet J., Verboven P., Derome D., Nicolai B. (2013), Novel application of neutron radiography to forced convective drying of fruit tissue, Food and Bioprocess Technology. (DOI:10.1007/s11947-012-0999-y)

Publisher version can be found at: $\underline{\text { http://link.springer.com/article/10.1007\%2Fs11947-012-0999-y }}$

within the sample, induced by drying, were found to be limited, and predominantly occurred at the air-material interface. Furthermore, the shrinkage behaviour of both samples (change in sample surface area and shrinkage profiles) was also similar.

Neutron imaging was shown to be capable of providing quantitative data of the water loss during drying of fruit and of the internal water distribution inside fruits, together with information on the sample shrinkage. Such data could be acquired quasi real-time, at a high spatial and dynamic resolution. Despite the limited accessibility to reactor facilities which produce neutrons, this technique is particularly valuable to study drying of food non-destructively, as it provides distinct advantages compared to, e.g., X-ray imaging, namely a high sensitivity to water. Furthermore, such experiments could provide detailed data for validation of numerical drying models, including information on the internal water transport, which is currently very scarce.

\section{Acknowledgements}

Thijs Defraeye is a postdoctoral fellow of the Research Foundation - Flanders (FWO) and acknowledges its support. The experiments were carried out at the NEUTRA beamline of the Paul Scherrer Institute, Villigen, Switzerland. We would like to acknowledge the contributions and support of the Paul Scherrer Institute NEUTRA support team. Financial support by the Research Foundation - Flanders (project FWO G.0603.08) and K.U.Leuven (project OT 08/023) is also gratefully acknowledged. 
Defraeye T., Aregawi W., Saneinejad S., Vontobel P., Lehmann E., Carmeliet J., Verboven P., Derome D., Nicolai B. (2013), Novel application of neutron radiography to forced convective drying of fruit tissue, Food and Bioprocess Technology. (DOI:10.1007/s11947-012-0999-y)

Publisher version can be found at: http://link.springer.com/article/10.1007\%2Fs11947-012-0999-y

\section{$\underline{\text { References }}$}

Abramoff MD, Magalhaes PJ \& Ram SJ (2004) Image Processing with ImageJ. Biophotonics International, 11(7), 3642.

Anderson IS, McGreevy R \& Bilheux HZ (eds.) (2009) Neutron Imaging and Applications - A Reference for the Imaging Community. Springer Science + Business Media, New York, USA.

Aregawi WA, Defraeye T, Verboven P, Herremans E, De Roeck G \& Nicolai B (2012) Modelling of coupled water transport and large deformation during dehydration of apple tissue. Food and Bioprocess Technology, $\underline{\text { Accepted. }}$

Balasko M, Koröusi F \& Farkas I (2002) Applying dynamic neutron radiography in in-situ monitoring of the drying processes of apple. Developments in Chemical Engineering and Mineral Processing, 10(3-4), 247-260.

De Bonis MV \& Ruocco G (2008) A generalized conjugate model for forced convection drying based on an evaporative kinetics. Journal of Food Engineering, 89(2), 232-240.

Dean RB (1978) Reynolds number dependence of skin friction and other bulk flow variables in two-dimensional rectangular duct flow. Transactions of the ASME: Journal of Fluids Engineering, 100, 215-223.

Defraeye T (2011) Convective heat and mass transfer at exterior building surfaces. PhD thesis. Department of Civil Engineering, KU Leuven, Belgium.

Defraeye T, Blocken B \& Carmeliet J (2012a) Analysis of convective heat and mass transfer coefficients for convective drying of a porous flat plate by conjugate modelling. International Journal of Heat and Mass Transfer, 55(1-3), 112124.

Defraeye T, Blocken B, Derome D, Nicolai B \& Carmeliet J (2012b) Convective heat and mass transfer modelling at air-porous material interfaces: overview of existing methods and relevance. Chemical Engineering Science, 74, 4958.

Esser HG, Carminati A, Vontobel P, Lehmann EH \& Oswald SE (2010) Neutron radiography and tomography of water distribution in the root zone. Journal of Plant Nutrition and Soil Science, 173(5), 757-764.

Fernandes FAN, Rodrigues S, Law CL \& Mujumdar AS (2011) Drying of exotic tropical fruits: a comprehensive review. Food and Bioprocess Technology, 4(2), 163-185.

Hassanein R (2006) Correction methods for the quantitative evaluation of thermal neutron tomography. PhD thesis, ETH Zurich, Switzerland.

Hassanein R, Lehmann E \& Vontobel P (2005) Methods of scattering corrections for quantitative neutron radiography. Nuclear Instruments and Methods in Physics Research Section A: Accelerators, Spectrometers, Detectors and Associated Equipment, 542(1-3), 353-360.

Hills BP \& Remigereau B (1997) NMR studies of changes in subcellular water compartmentation in parenchyma apple tissue during drying and freezing. International Journal of Food Science \& Technology, 32(1), 51-61.

Kaya A, Aydin O \& Dincer I (2006) Numerical modeling of heat and mass transfer during forced convection drying of rectangular moist objects. International Journal of Heat and Mass Transfer, 49(17-18), 3094-3103.

Lamnatou Chr, Papanicolaou E, Belessiotis V \& Kyriakis N (2009) Conjugate heat and mass transfer from a drying rectangular cylinder in confined air flow. Numerical Heat Transfer, Part A: Applications, 56(5), 379-405.

Lamnatou Chr, Papanicolaou E, Belessiotis V \& Kyriakis N (2010) Finite-volume modelling of heat and mass transfer during convective drying of porous bodies - Non-conjugate and conjugate formulations involving the aerodynamic effects. Renewable Energy, 35(7), 1391-1402. 
Defraeye T., Aregawi W., Saneinejad S., Vontobel P., Lehmann E., Carmeliet J., Verboven P., Derome D., Nicolai B. (2013), Novel application of neutron radiography to forced convective drying of fruit tissue, Food and Bioprocess Technology. (DOI:10.1007/s11947-012-0999-y)

Publisher version can be found at: http://link.springer.com/article/10.1007\%2Fs11947-012-0999-y

Lehmann E, Vontobel P \& Wiezel L (2001) Properties of the radiography facility NEUTRA at SINQ and its potential for use as European reference facility. Nondestructive Testing and Evaluation, 16, 191-202.

Leonard A, Blacher S, Marchot P, Pirard JP \& Crine M (2004) Measurement of shrinkage and cracks associated to convective drying of soft materials by X-ray microtomography. Drying Technology, 22(7), 1695-1708.

Leonard A, Blacher S, Marchot P, Pirard JP \& Crine M (2005) Moisture profiles determination during convective drying using X-ray microtomography. Canadian Journal of Chemical Engineering, 83, 127-131.

Leonard A, Blacher S, Nimmol C \& Devahastin S (2008) Effect of far-infrared radiation assisted drying on microstructure of banana slices: An illustrative use of X-ray microtomography in microstructural evaluation of a food product. Journal of Food Engineering, 85(1), 154-162.

Marquez CA \& De Michelis A (2011) Comparison of drying kinetics for small fruits with and without particle shrinkage considerations. Food and Bioprocess Technology, 4(7), 1212-1218.

Matsushima U, Herppich WB, Kardjilov N, Graf W, Hilger A \& Manke I (2009) Estimation of water flow velocity in small plants using cold neutron imaging with $\mathrm{D}_{2} \mathrm{O}$ tracer. Nuclear Instruments and Methods in Physics Research Section A: Accelerators, Spectrometers, Detectors and Associated Equipment, 605(1-2), 146-149.

Matsushima U, Kawabata Y \& Horie T (2005b) Estimation of the volumetric water content in chrysanthemum tissues. Journal of Radioanalytical and Nuclear Chemistry, 264(2), 325-328.

Matsushima U, Kawabata Y, Hino M, Geltenbort P \& Nicolaï BM (2005a) Measurement of changes in water thickness in plant materials using very low-energy neutron radiography. Nuclear Instruments and Methods in Physics Research Section A: Accelerators, Spectrometers, Detectors and Associated Equipment, 542(1-3), 76-80.

McCarthy MJ, Perez E \& Ozilgen M (1991) Model for transient moisture profiles of a drying apple slab using the data obtained with magnetic resonance imaging. Biotechnology Progress, 7(6), 540-543.

Menon M, Robinson B, Oswald SE, Kaestner A, Abbaspour KC, Lehmann E \& Schulin R (2007) Visualization of root growth in heterogeneously contaminated soil using neutron radiography. European Journal of Soil Science, 58(3), $802-810$.

Misra S, Ramesh KT \& Okamura AM (2008) Modeling of tool-tissue interactions for computer-based surgical simulation: a literature review. Presence (Camb), 17(5), 463 (41p).

Mujumdar AS \& Law CL (2010) Drying technology: trends and applications in postharvest processing. Food and Bioprocess Technology, 3(6), 843-852.

Mujumdar AS (ed) (2006) Handbook of Industrial Drying. Taylor \& Francis Group, Boca Raton, USA.

Nakanishi TM \& Matsubayashi M (1997a) Nondestructive water imaging by neutron beam analysis in living plants. Journal of Plant Physiology, 151(4), 442-445.

Nakanishi TM \& Matsubayashi M (1997b) Water imaging of seeds by neutron beam. Bioimages 5, 45-48.

Nakanishi TM, Furukawa J \& Matsubayashi M (1999) A preliminary study of CT imaging of water in a carnation flower. Nuclear Instruments and Methods in Physics Research A, 424, 136-141.

Nguyen TA, Dresselaers T, Verboven P, D'hallewin G, Culeddu N, Van Hecke P \& Nicolai B (2006b) Finite element modelling and MRI validation of 3D transient water profiles in pears during postharvest storage. Journal of the Science of Food and Agriculture, 86(5), 745-756.

Nguyen TA, Verboven P, Scheerlinck N, Vandewalle S \& Nicolai BM (2006a) Estimation of effective diffusivity of pear tissue and cuticle by means of a numerical water diffusion model. Journal of Food Engineering, 72(1), 63-72. 
Defraeye T., Aregawi W., Saneinejad S., Vontobel P., Lehmann E., Carmeliet J., Verboven P., Derome D., Nicolai B. (2013), Novel application of neutron radiography to forced convective drying of fruit tissue, Food and Bioprocess Technology. (DOI:10.1007/s11947-012-0999-y)

Publisher version can be found at: $\underline{\text { http://link.springer.com/article/10.1007\%2Fs11947-012-0999-y }}$

Nguyen TA, Verboven P, Schenk A \& Nicolaï B (2007) Prediction of water loss from pears (Pyrus communis cv.Conference) during controlled atmosphere storage as affected by relative humidity. Journal of Food Engineering, 83(2), 149-155.

Ratti C (2001) Hot air and freeze-drying of high-value foods: a review. Journal of Food Engineering, 49(4), 311-319.

Sedighi-Gilani M, Griffa M, Mannes D, Lehmann E, Carmeliet J \& Derome D (2012), Visualization and quantification of liquid water transport in softwood by means of neutron radiography. International Journal Heat and Mass Transport, Accepted.

Veraverbeke EA, Verboven P, Scheerlinck N, Hoang ML \& Nicolai B (2003a) Determination of the diffusion coefficient of tissue, cuticle, cutin and wax of apple. Journal of Food Engineering, 58(3), 285-294.

Veraverbeke EA, Verboven P, Van Oostveldt P \& Nicolaï B (2003b) Prediction of moisture loss across the cuticle of apple (Malus sylvestris subsp mitis (Wallr.)) during storage Part 1. Model development and determination of diffusion coefficients. Postharvest Biology and Technology, 30(1), 75-88.

Veraverbeke EA, Verboven P, Van Oostveldt P \& Nicolaï B (2003c) Prediction of moisture loss across the cuticle of apple (Malus sylvestris subsp mitis (Wallr.)) during storage Part 2. Model simulations and practical applications. Postharvest Biology and Technology, 30(1), 89-97.

Verboven P, Kerckhofs G, Mebatsion HK, Ho QT, Temst K, Wevers M, Cloetens P \& Nicolai BM (2008) Threedimensional gas exchange pathways in pome fruit characterized by synchrotron x-ray computed tomography. Plant Physiology, 147(2), 518-527.

Verstreken E, Van Hecke P, Scheerlinck N, De Baerdemaeker J \& Nicolaï B (1998) Parameter estimation for moisture transport in apples with the aid of NMR imaging. Magnetic Resonance in Chemistry, 36(3), 196-204. 
Defraeye T., Aregawi W., Saneinejad S., Vontobel P., Lehmann E., Carmeliet J., Verboven P., Derome D., Nicolai B. (2013), Novel application of neutron radiography to forced convective drying of fruit tissue, Food and Bioprocess Technology. (DOl:10.1007/s11947-012-0999-y)

Publisher version can be found at: http://link.springer.com/article/10.1007\%2Fs11947-012-0999-y

Figure captions

\section{Side view}

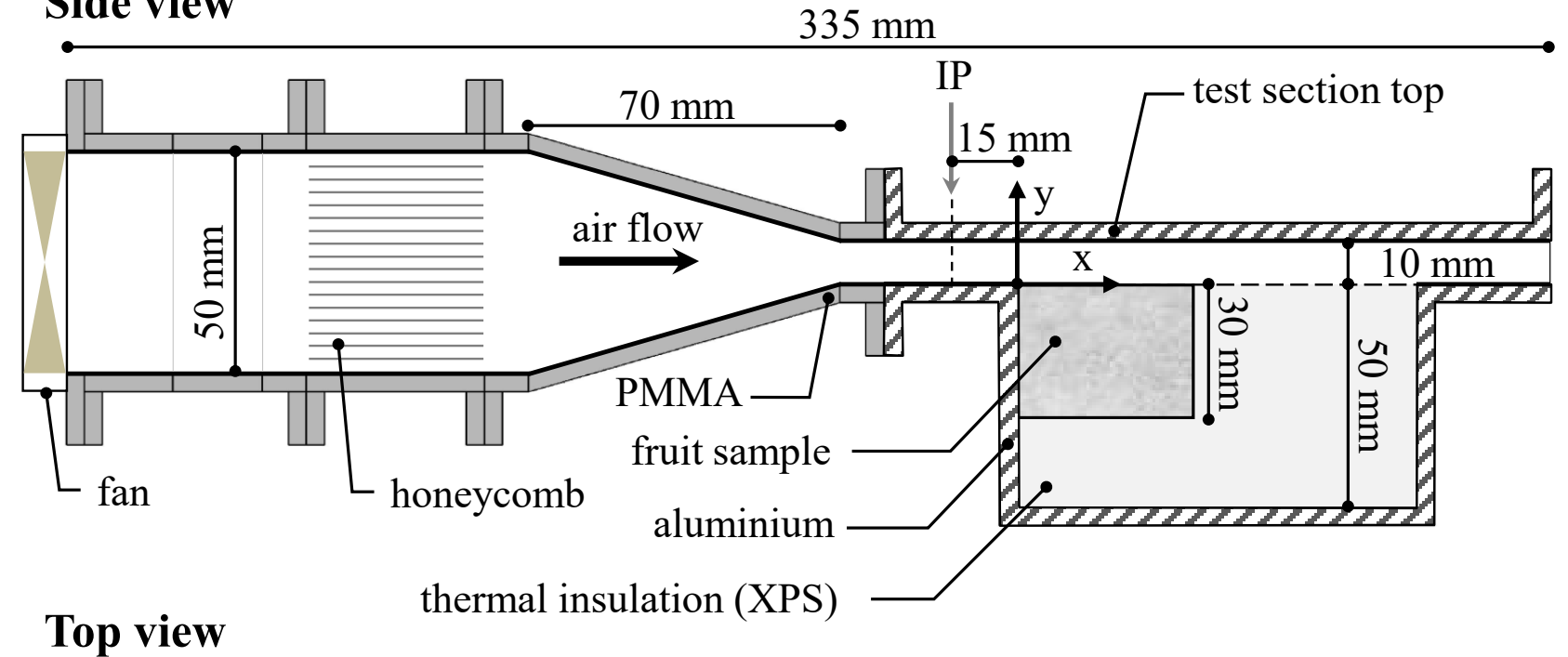

Top view

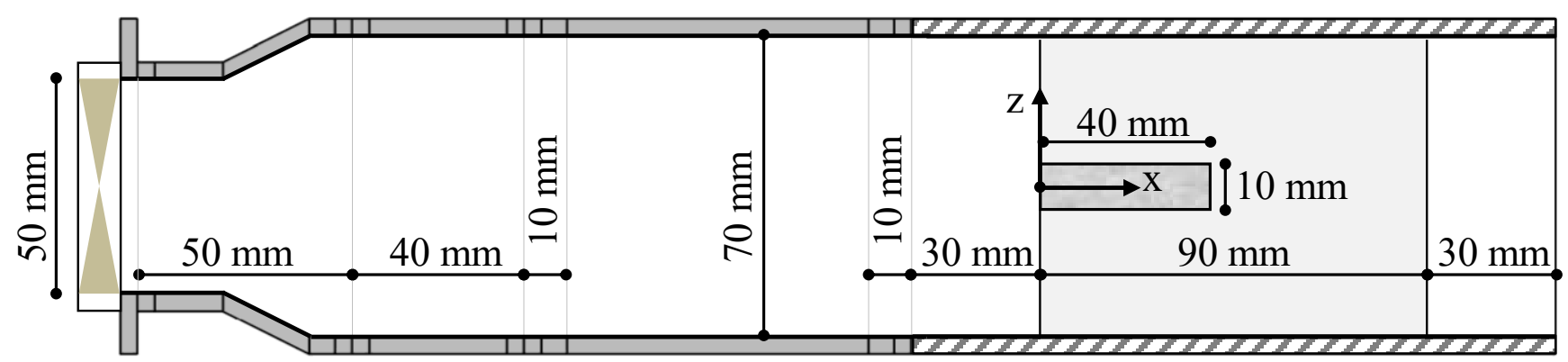

Figure 1. Wind-tunnel setup with indication of different components (IP: location where inlet profile is measured with PIV, PMMA: polymethyl methacrylate). 
Defraeye T., Aregawi W., Saneinejad S., Vontobel P., Lehmann E., Carmeliet J., Verboven P., Derome D., Nicolai B. (2013), Novel application of neutron radiography to forced convective drying of fruit tissue, Food and Bioprocess Technology. (DOI:10.1007/s11947-012-0999-y)

Publisher version can be found at: http://link.springer.com/article/10.1007\%2Fs11947-012-0999-y

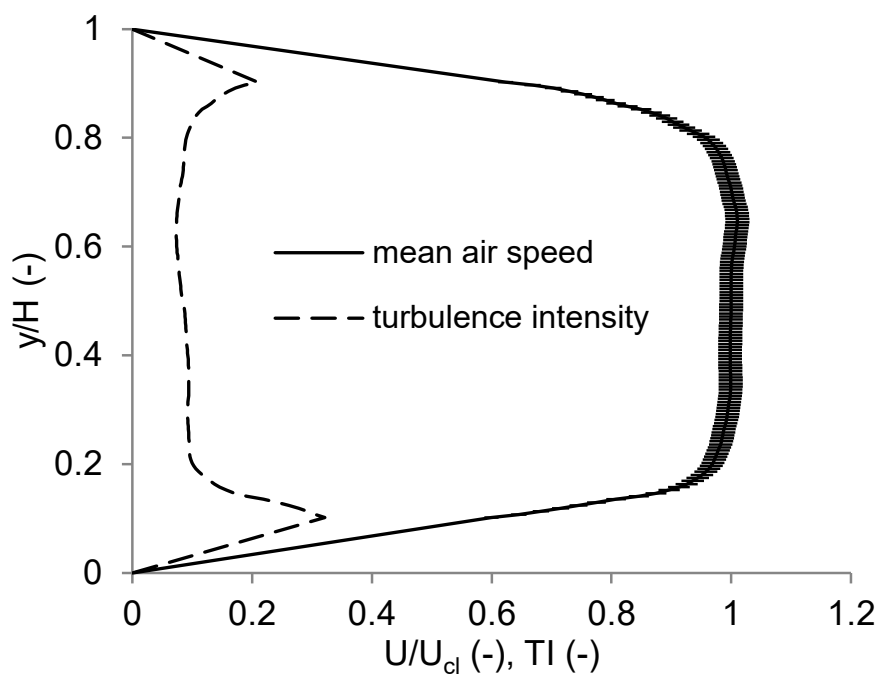

Figure 2: Profiles of mean air speed ( $U$, made dimensionless with the centreline velocity, $U_{c l}$, with error bars) and turbulence intensity (TI) in the centre of the channel $(z=0)$ at the inlet (location IP, see Figure 1). 
Defraeye T., Aregawi W., Saneinejad S., Vontobel P., Lehmann E., Carmeliet J., Verboven P., Derome D., Nicolai B. (2013), Novel application of neutron radiography to forced convective drying of fruit tissue, Food and Bioprocess Technology. (DOI:10.1007/s11947-012-0999-y)

Publisher version can be found at: http://link.springer.com/article/10.1007\%2Fs11947-012-0999-y

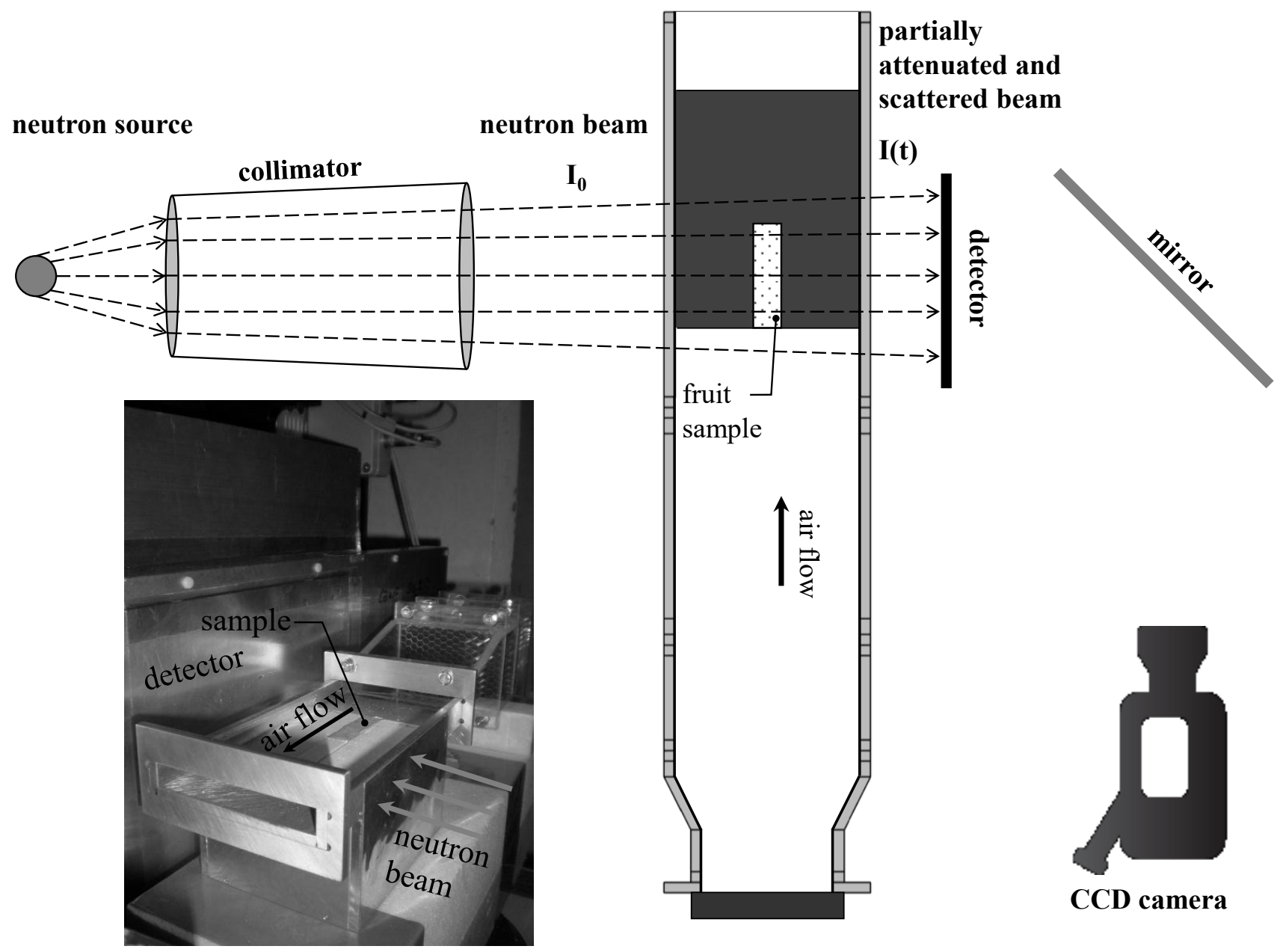

Figure 3. Schematic overview of the experimental setup for neutron radiography and picture of the actual setup (without removable top section of the test section) in the NEUTRA beamline. 
Defraeye T., Aregawi W., Saneinejad S., Vontobel P., Lehmann E., Carmeliet J., Verboven P., Derome D., Nicolai B. (2013), Novel application of neutron radiography to forced convective drying of fruit tissue, Food and Bioprocess Technology. (DOl:10.1007/s11947-012-0999-y)

Publisher version can be found at: http://link.springer.com/article/10.1007\%2Fs11947-012-0999-y
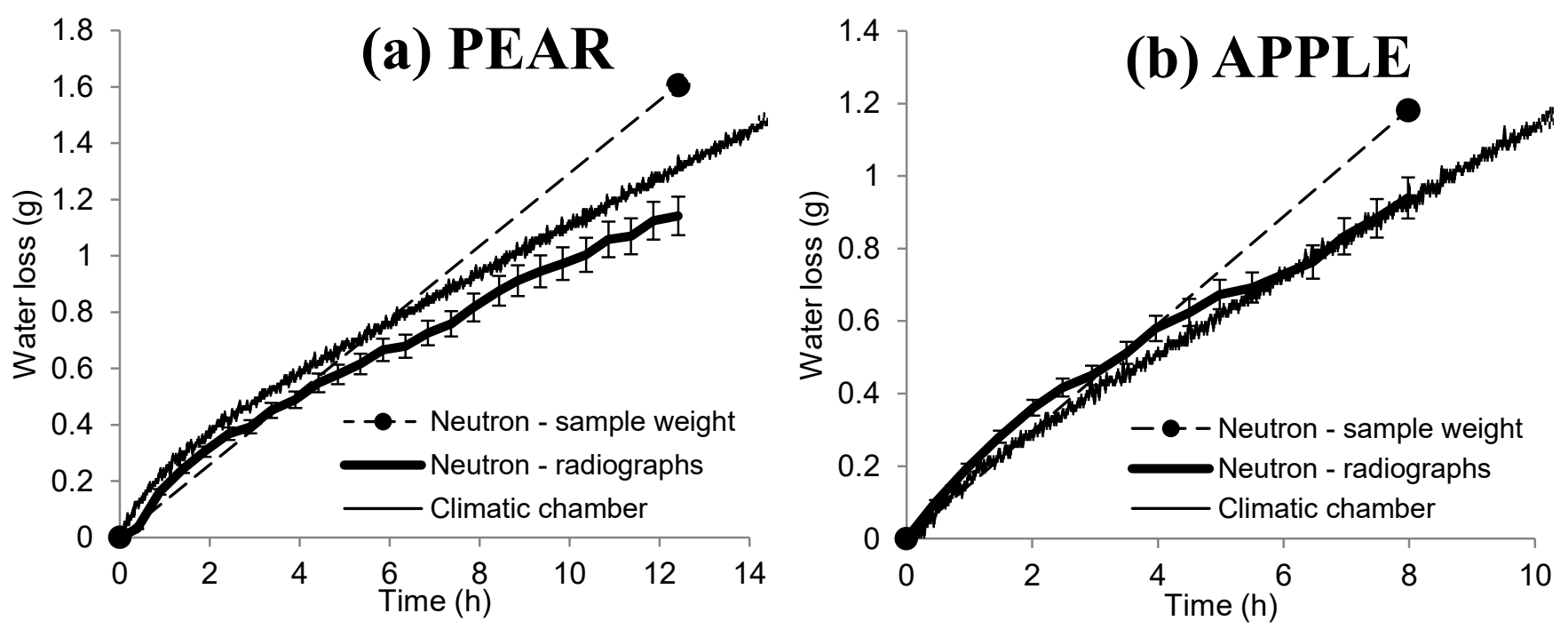

Figure 4. Water loss from fruit samples (pear (a) and apple (b)) during drying. Comparison between results from neutron radiographs, sample water loss for the neutron experiments (difference between initial and end weight), and experiments in the climatic chamber (without neutron beam, gravimetrically), with error bars. 
Defraeye T., Aregawi W., Saneinejad S., Vontobel P., Lehmann E., Carmeliet J., Verboven P., Derome D., Nicolai B. (2013), Novel application of neutron radiography to forced convective drying of fruit tissue, Food and Bioprocess Technology. (DOl:10.1007/s11947-012-0999-y)

Publisher version can be found at: http://link.springer.com/article/10.1007\%2Fs11947-012-0999-y
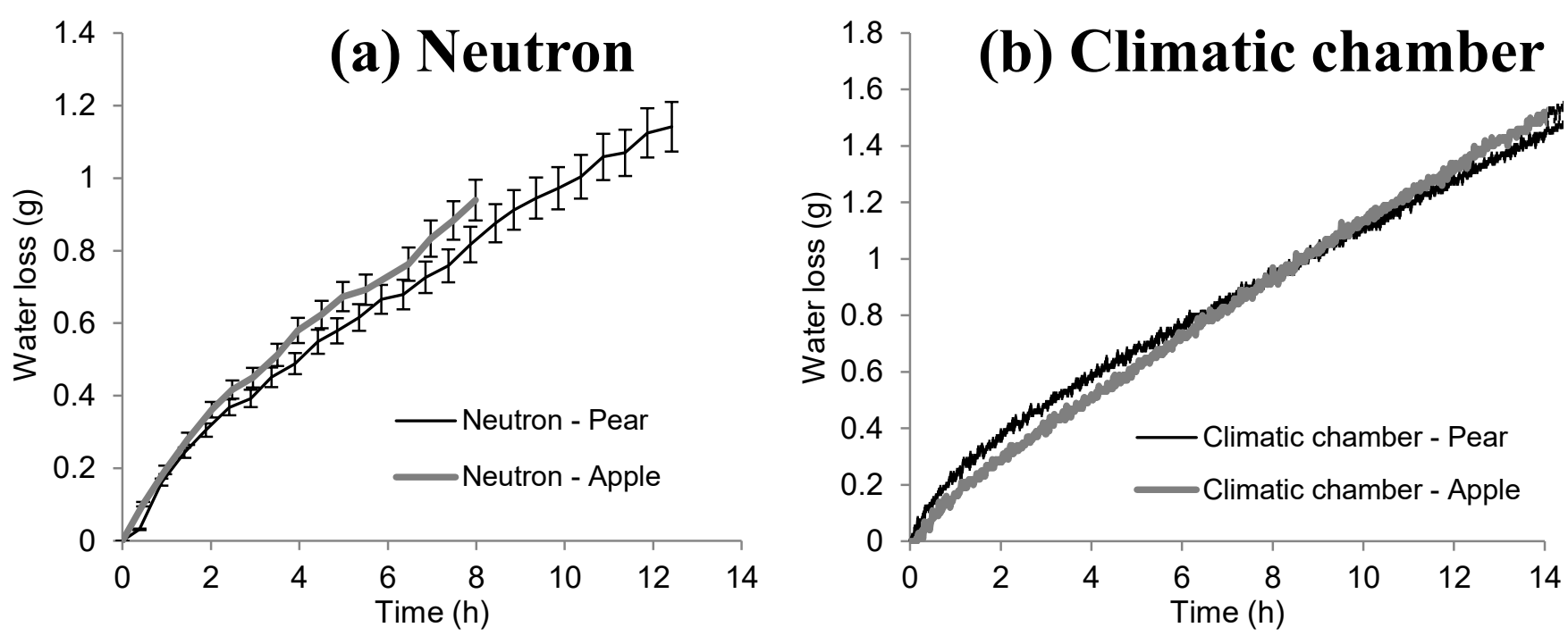

Figure 5. Water loss from fruit samples (pear (a) and apple (b)) during drying from neutron experiments (radiographs) and experiments in the climatic chamber (without neutron beam, gravimetrically). Comparison between pear and apple fruit, with error bars. 
Defraeye T., Aregawi W., Saneinejad S., Vontobel P., Lehmann E., Carmeliet J., Verboven P., Derome D., Nicolai B. (2013), Novel application of neutron radiography to forced convective drying of fruit tissue, Food and Bioprocess Technology. (DOI:10.1007/s11947-012-0999-y)

Publisher version can be found at: $\underline{\text { http://link.springer.com/article/10.1007\%2Fs11947-012-0999-y }}$

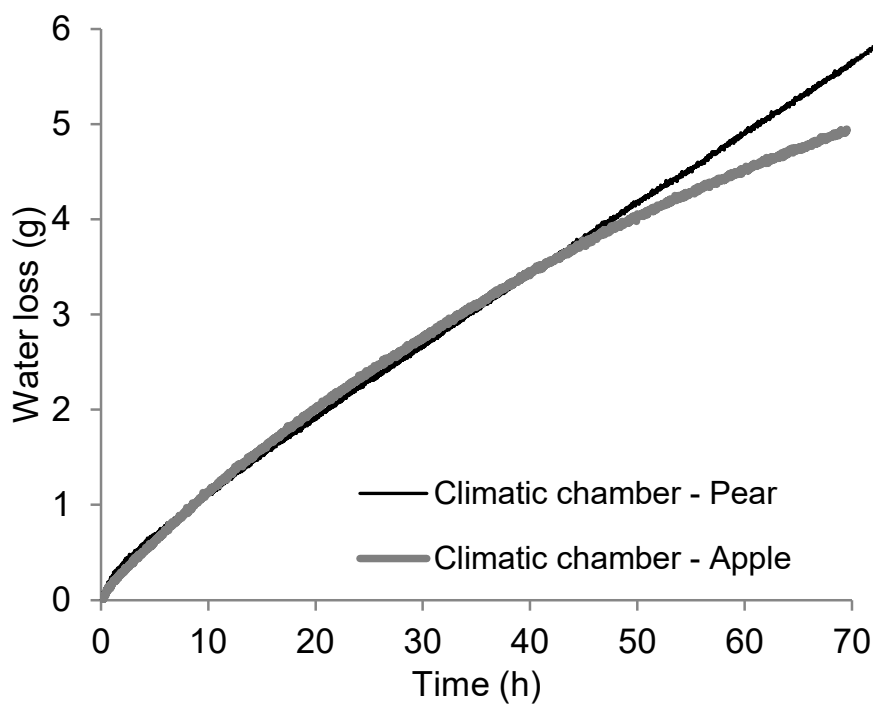

Figure 6. Water loss from fruit samples (pear and apple) during drying from experiments in the climatic chamber (without neutron beam, gravimetrically) for a long time span, with error bars. 
Defraeye T., Aregawi W., Saneinejad S., Vontobel P., Lehmann E., Carmeliet J., Verboven P., Derome D., Nicolai B. (2013), Novel application of neutron radiography to forced convective drying of fruit tissue, Food and Bioprocess Technology. (DOI:10.1007/s11947-012-0999-y)

Publisher version can be found at: http://link.springer.com/article/10.1007\%2Fs11947-012-0999-y

\section{(a) PEAR}
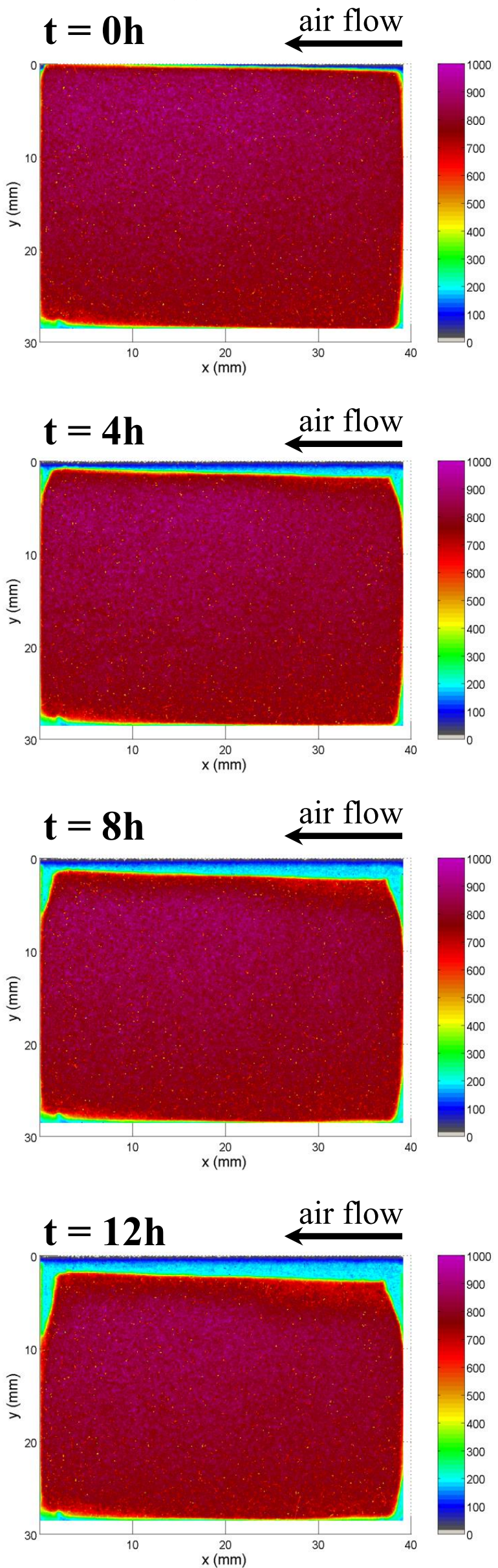

(b) APPLE
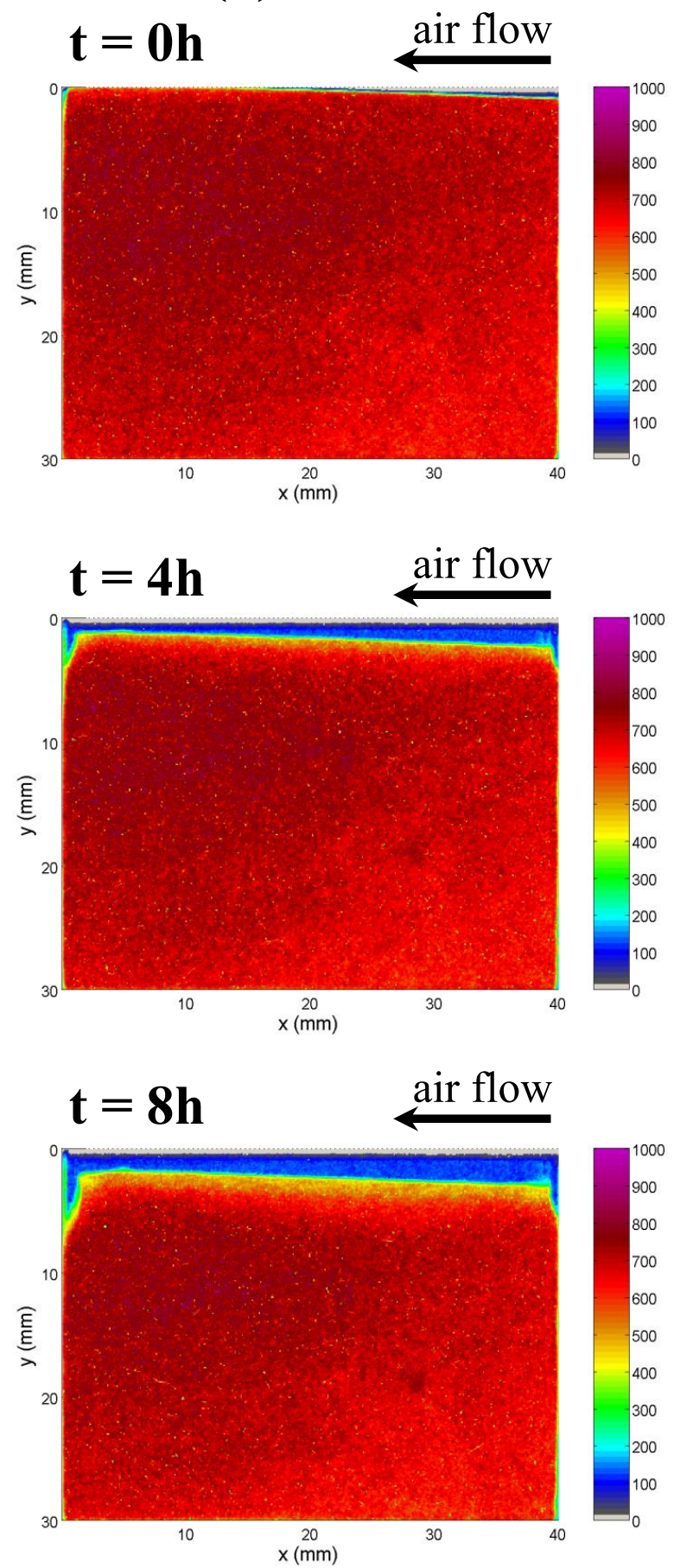
Defraeye T., Aregawi W., Saneinejad S., Vontobel P., Lehmann E., Carmeliet J., Verboven P., Derome D., Nicolai B. (2013), Novel application of neutron radiography to forced convective drying of fruit tissue, Food and Bioprocess Technology. (DOI:10.1007/s11947-012-0999-y)

Publisher version can be found at: http://link.springer.com/article/10.1007\%2Fs11947-012-0999-y

(a) PEAR
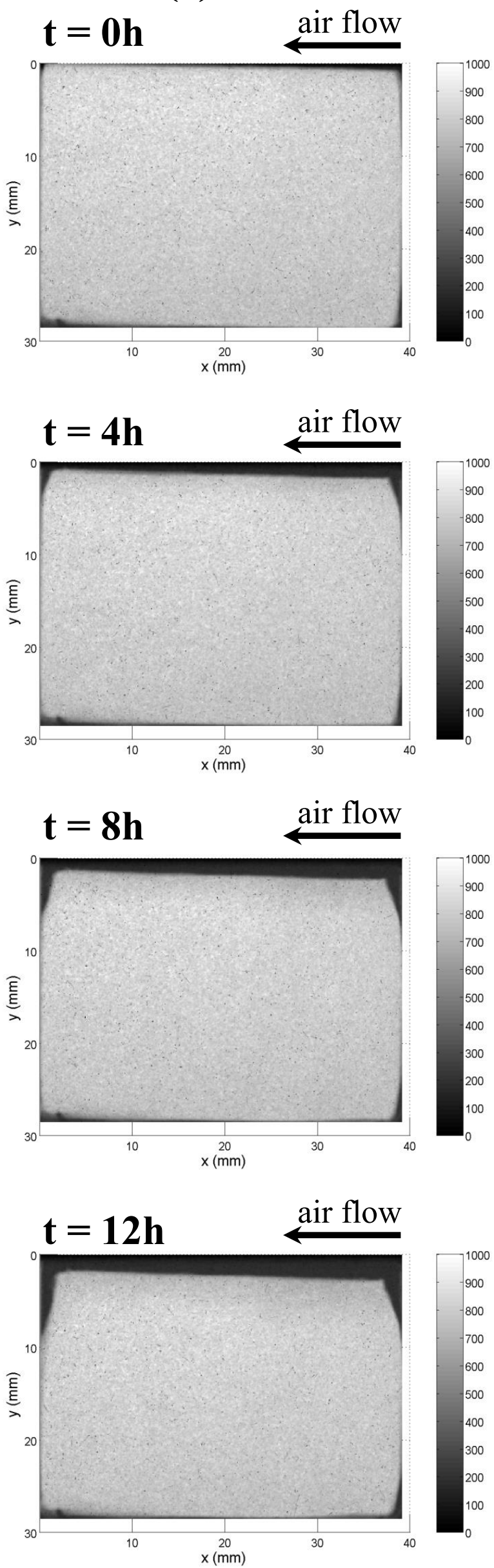

(b) APPLE
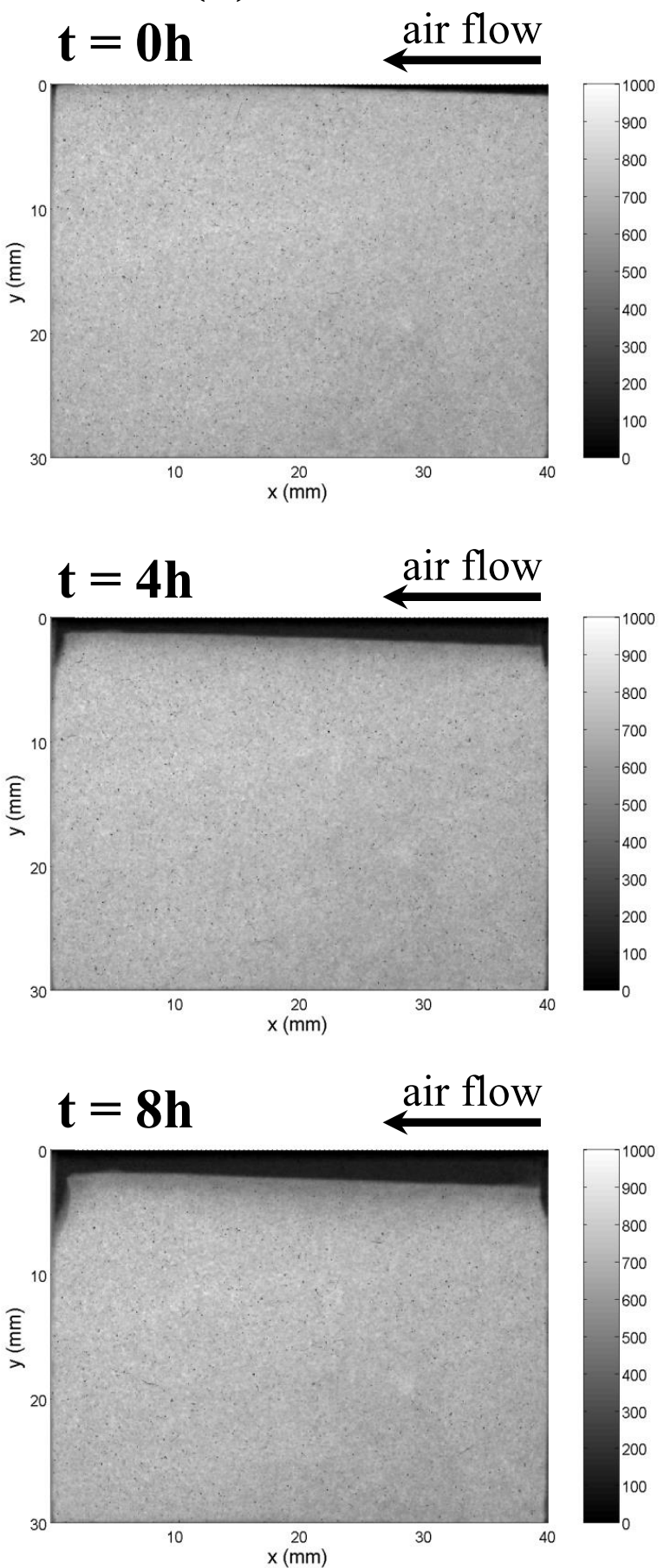
Defraeye T., Aregawi W., Saneinejad S., Vontobel P., Lehmann E., Carmeliet J., Verboven P., Derome D., Nicolai B. (2013), Novel application of neutron radiography to forced convective drying of fruit tissue, Food and Bioprocess Technology. (DOI:10.1007/s11947-012-0999-y)

Publisher version can be found at: $\underline{\text { http://link.springer.com/article/10.1007\%2Fs11947-012-0999-y }}$

Figure 7. Internal distribution of water content $\left(\mathrm{kg} \mathrm{m}^{-3}\right)$ from neutron radiographs for pear (a) and apple (b) fruit at different times. The air-material interface (air flow) is located at the top of the images $(y \approx 0 \mathrm{~mm})$ and the leading edge at $x \approx 40 \mathrm{~mm}$. These coordinates are different from Figure 1, where the $y$-coordinate is negative and the origin is located at $x=0 \mathrm{~mm}$. 
Defraeye T., Aregawi W., Saneinejad S., Vontobel P., Lehmann E., Carmeliet J., Verboven P., Derome D., Nicolai B. (2013), Novel application of neutron radiography to forced convective drying of fruit tissue, Food and Bioprocess Technology. (DOI:10.1007/s11947-012-0999-y)

Publisher version can be found at: http://link.springer.com/article/10.1007\%2Fs11947-012-0999-y

\section{(a) PEAR}
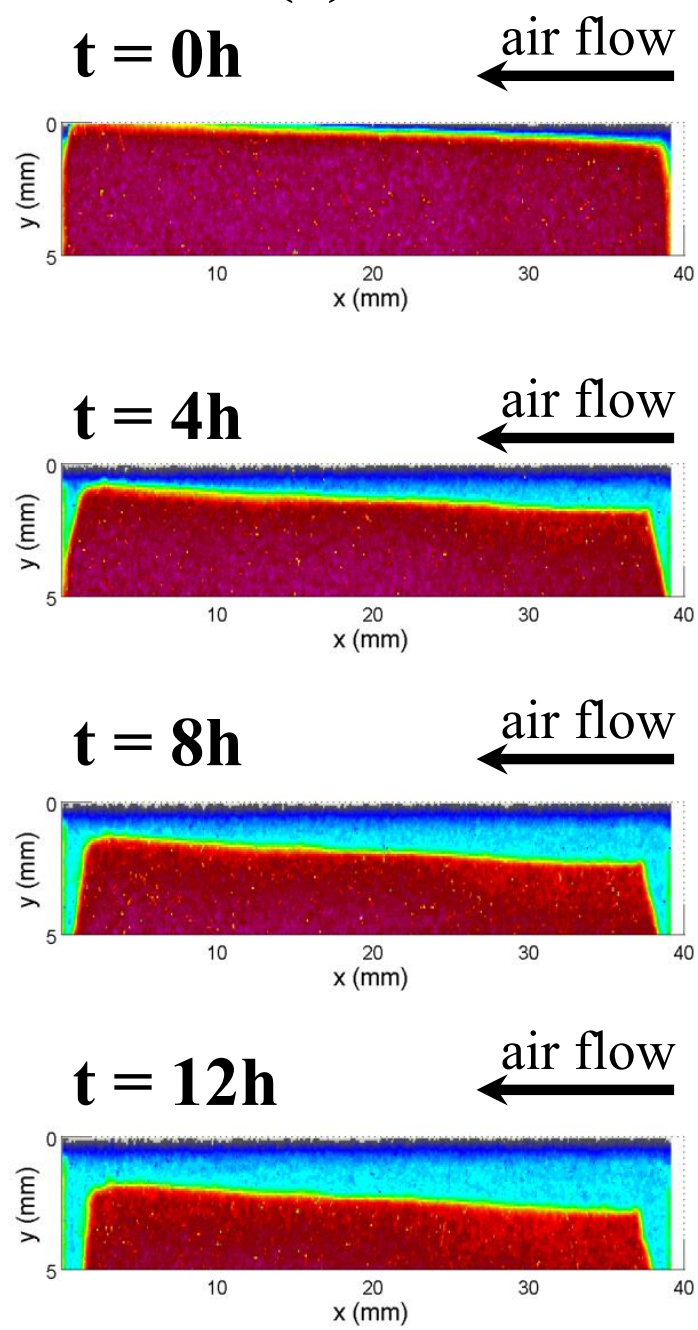

(b) APPLE
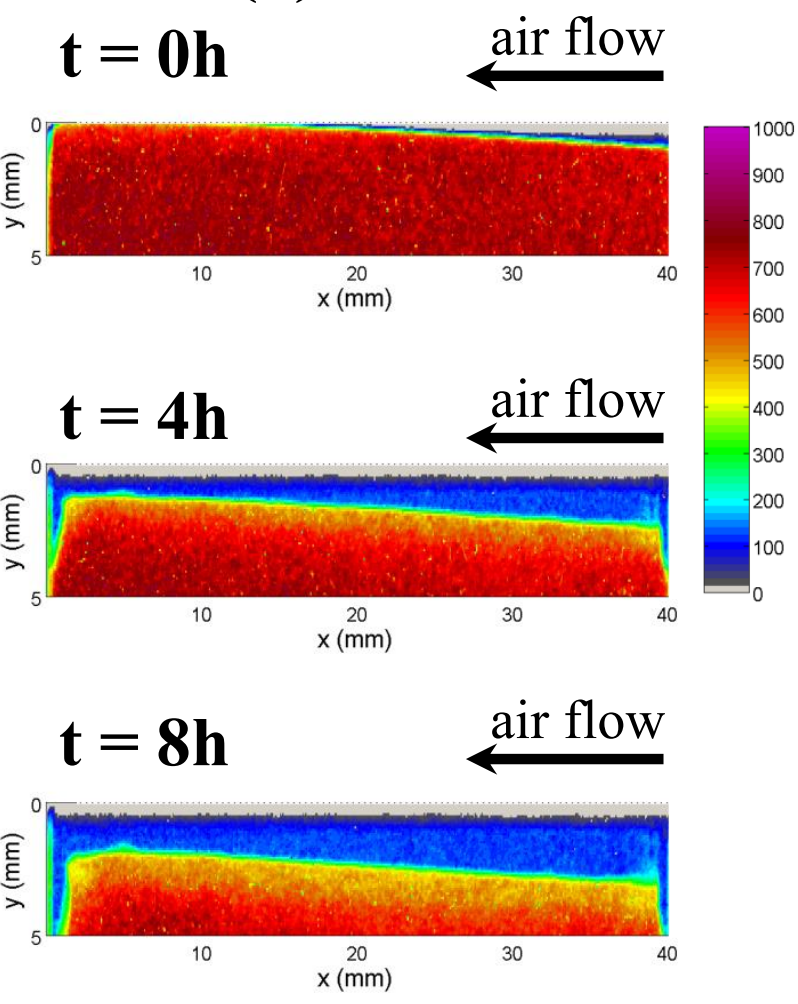


\section{(a) PEAR}

$$
\mathbf{t}=\mathbf{0 h}
$$
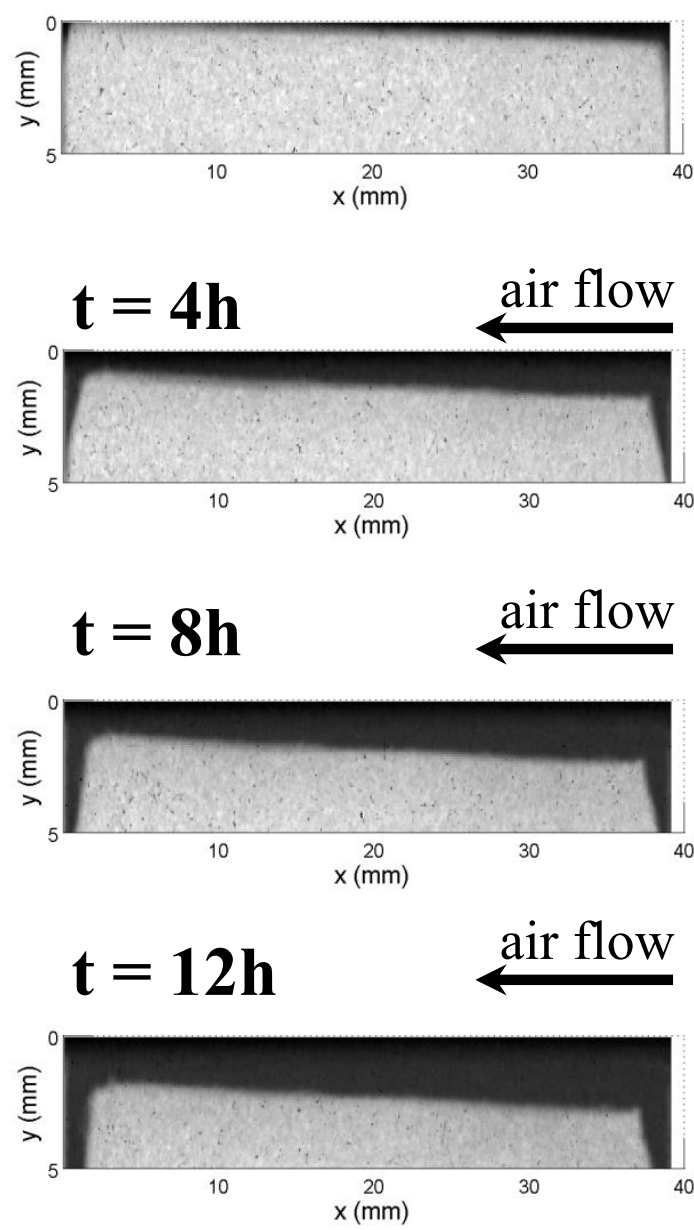

(b) APPLE
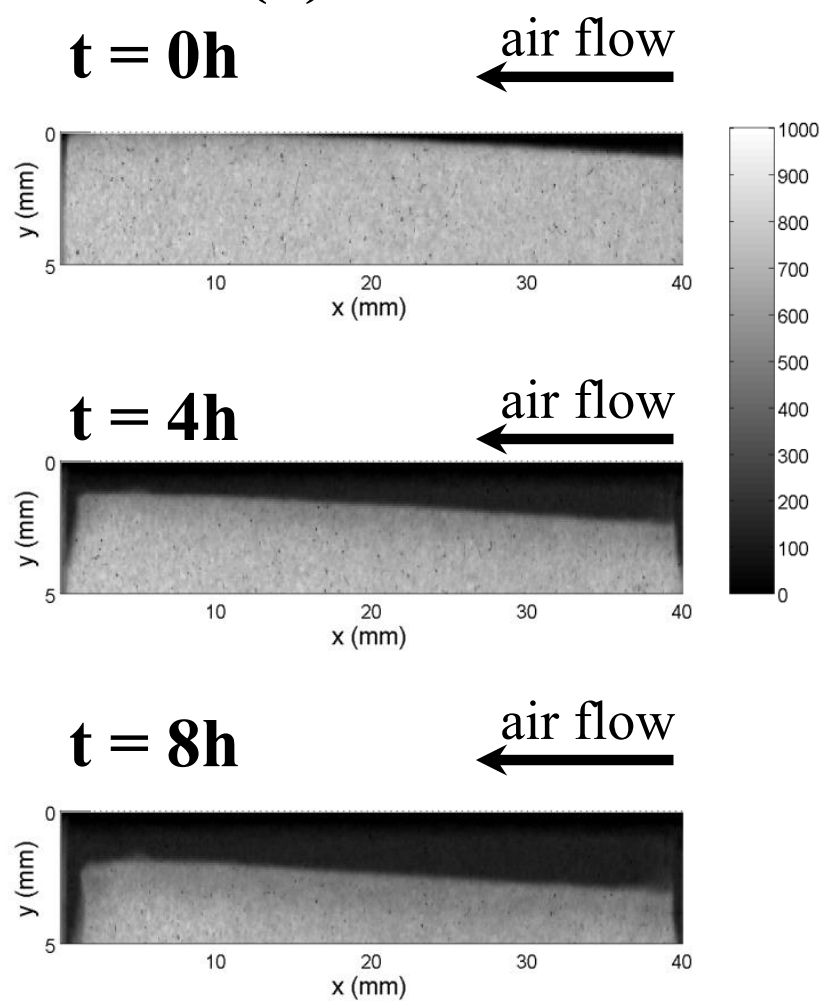

Figure 8. Internal distribution of water content $\left(\mathrm{kg} \mathrm{m}^{-3}\right)$ from neutron radiographs for pear (a) and apple (b) fruit at different times. Close-up of the upper part $(5 \mathrm{~mm})$ of the sample. The air-material interface (air flow) is located at the top of the images $(y \approx 0 \mathrm{~mm})$ and the leading edge at $x \approx 40 \mathrm{~mm}$. These coordinates are different from Figure 1, where the $y$-coordinate is negative and the origin is located at $x=0 \mathrm{~mm}$. 
Defraeye T., Aregawi W., Saneinejad S., Vontobel P., Lehmann E., Carmeliet J., Verboven P., Derome D., Nicolai B. (2013), Novel application of neutron radiography to forced convective drying of fruit tissue, Food and Bioprocess Technology. (DOI:10.1007/s11947-012-0999-y)

Publisher version can be found at: http://link.springer.com/article/10.1007\%2Fs11947-012-0999-y
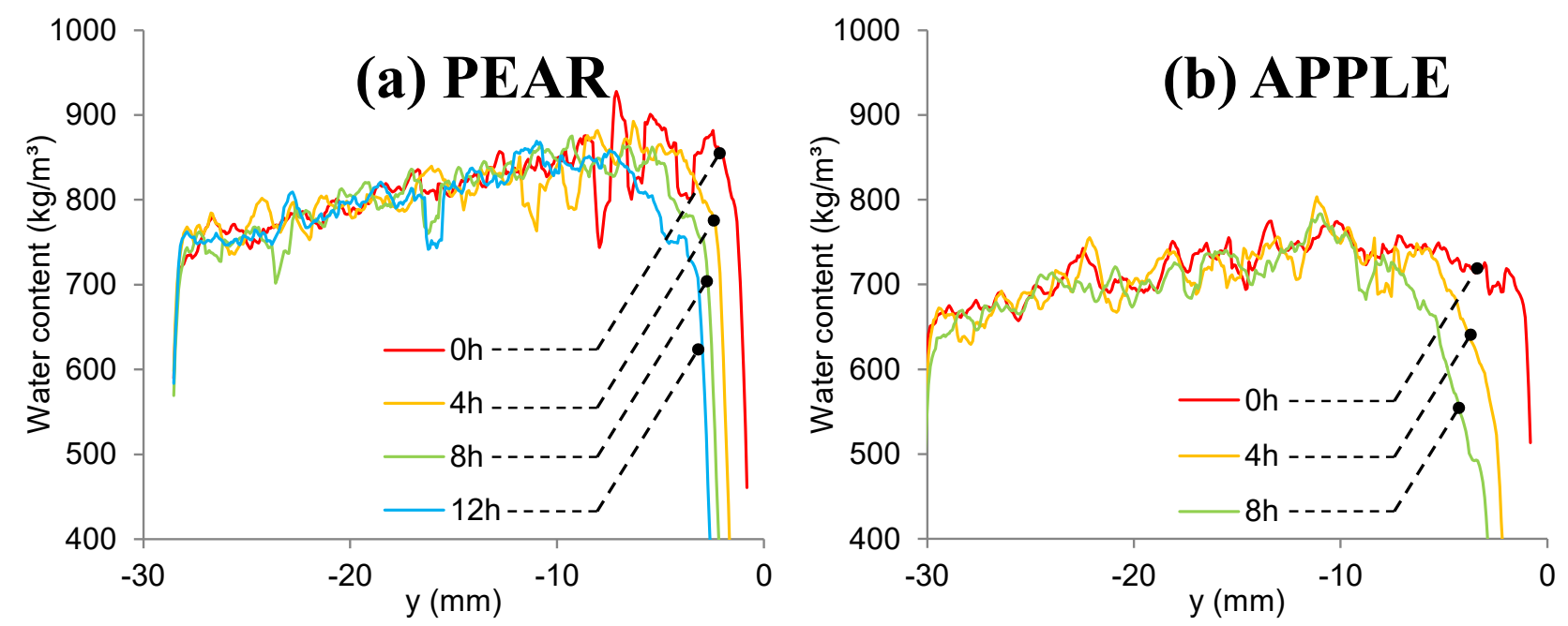

Figure 9. Internal distribution of water content from neutron radiographs for pear (a) and apple (b) fruit at different times along profiles in the centreline of the sample $(x=20 \mathrm{~mm}$, see Figure 1). The air-material interface (air flow) is located near $y \approx 0 \mathrm{~mm}$. The error bars (5\% on the water content) are not represented to improve the clarity of the figure. 
Defraeye T., Aregawi W., Saneinejad S., Vontobel P., Lehmann E., Carmeliet J., Verboven P., Derome D., Nicolai B. (2013), Novel application of neutron radiography to forced convective drying of fruit tissue, Food and Bioprocess Technology. (DOl:10.1007/s11947-012-0999-y)

Publisher version can be found at: http://link.springer.com/article/10.1007\%2Fs11947-012-0999-y
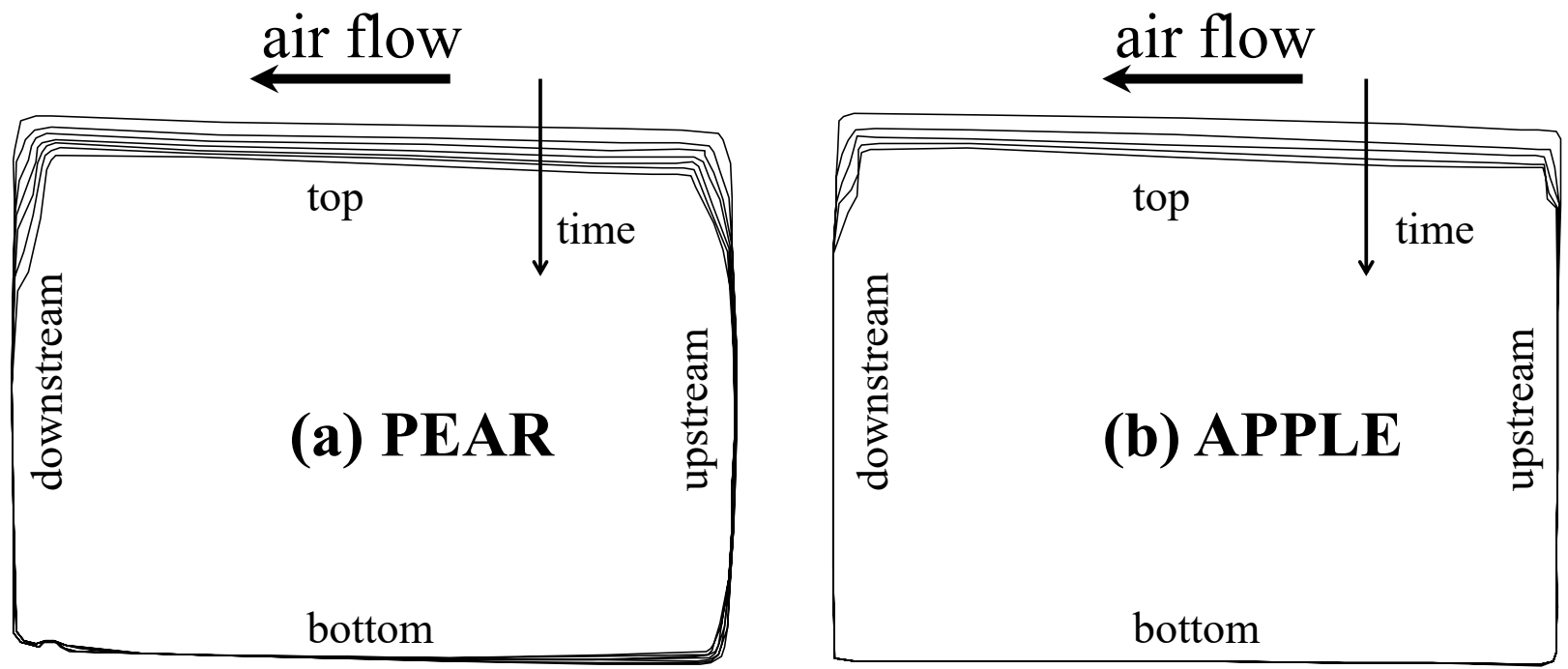

Figure 10. Contours of change in sample surface area with time during drying, determined from the (2D) neutron radiographs for pear (a) and apple (b) fruit. Note that the drying time of pear is $12 \mathrm{~h}$ and for apple it is $8 \mathrm{~h}$. Air flow is present at the top of the sample. 
Defraeye T., Aregawi W., Saneinejad S., Vontobel P., Lehmann E., Carmeliet J., Verboven P., Derome D., Nicolai B. (2013), Novel application of neutron radiography to forced convective drying of fruit tissue, Food and Bioprocess Technology. (DOI:10.1007/s11947-012-0999-y)

Publisher version can be found at: http://link.springer.com/article/10.1007\%2Fs11947-012-0999-y

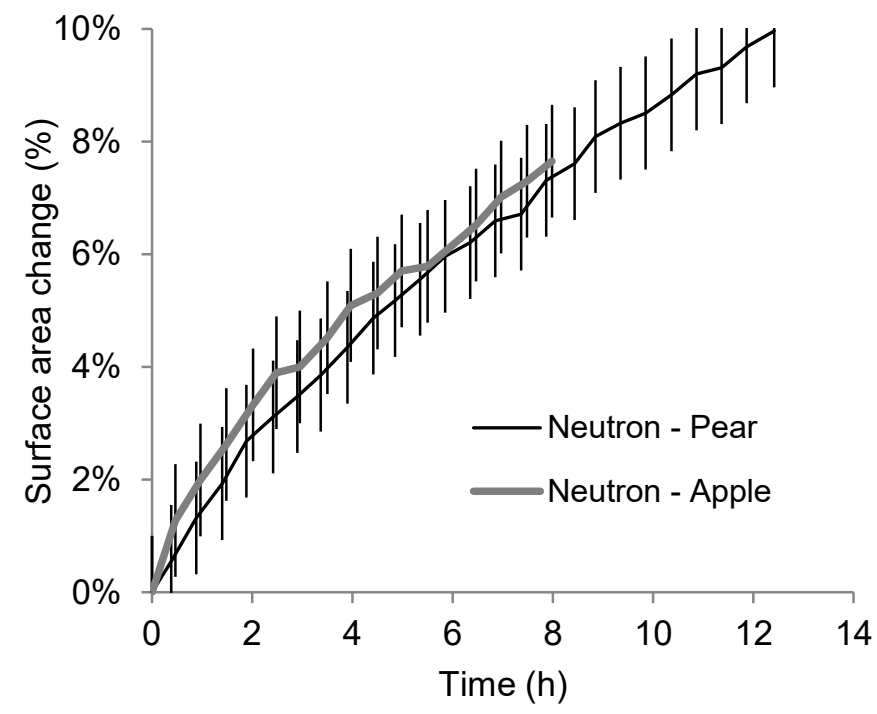

Figure 11. Percentage change of (2D) sample surface area with time during drying, determined from the (2D) neutron radiographs for pear and apple fruit, with error bars. 
Defraeye T., Aregawi W., Saneinejad S., Vontobel P., Lehmann E., Carmeliet J., Verboven P., Derome D., Nicolai B. (2013), Novel application of neutron radiography to forced convective drying of fruit tissue, Food and Bioprocess Technology. (DOI:10.1007/s11947-012-0999-y)

Publisher version can be found at: $\underline{\text { http://link.springer.com/article/10.1007\%2Fs11947-012-0999-y }}$

\section{Tables}

Table 1. Characteristics of pear and apple samples used in the experiments.

\begin{tabular}{lcc}
\hline & Sample dimensions $(x, y, z)\left(\mathrm{mm}^{3}\right)$ & Initial water content $\left(w_{\text {ini }}, \mathrm{kg} \mathrm{\textrm {m } ^ { - 3 } )}\right.$ \\
\hline Neutron experiments & & \\
\hline Pear (cv. Conference) & $38.8 \times 28.5 \times 11.0$ & 802 \\
\hline Apple (cv. Maigold) & $40.0 \times 29.6 \times 10.5$ & 703 \\
\hline Experiments in climatic chamber & & 898 \\
\hline Pear (cv. Conference) & $39.0 \times 28.4 \times 10.4$ & 712 \\
\hline Apple (cv. Braeburn) & $38.8 \times 29.1 \times 11.2$ & \\
\hline
\end{tabular}

Table 2. Diffusion coefficients $\left(\mathrm{m}^{2} \mathrm{~s}^{-1}\right)$ of pear (from Nguyen et al., 2006a; including standard deviation) and apple (from Veraverbeke et al., 2003a).

\begin{tabular}{llcc}
\hline Species & Cultivar & Diffusion coefficient & Standard deviation \\
\hline Pear & & & \\
\hline & Conference (inner tissue) & $43.6 \times 10^{-12}$ & $10.8 \times 10^{-12}$ \\
\hline Apple & Conference (outer tissue) & $1.05 \times 10^{-12}$ & $0.15 \times 10^{-12}$ \\
\hline & Jonagold & $11.2 \times 10^{-12}$ & \\
\hline & Elstar & $4.33 \times 10^{-12}$ & \\
\hline & Jonagored & $13.8 \times 10^{-12}$ & \\
\hline
\end{tabular}

